\title{
Acerca de la cerámica Tiwanaku y una vasija del valle de Azapa (Arica, Norte Grande de Chile) ${ }^{1}$
}

\section{RESUMEN}

La intención de este artículo ha sido contribuir a la comprensión de la problemática Tiwanaku en Arica, usando como "excusa" el redescubrimiento de una vasija excepcional, proveniente del sitio funerario Az-71 a del valle de Azapa excavado por G. Focacci. Lo significativo de la vasija es que la pintura reproduce no sólo la imagen, sino también el antiquísimo tema del "Señor de los Cetros", cuya manifestación es prácticamente inexistente en la alfarería y más bien privativa de la escultura lítica del altiplano. De hecho, esta sería la única manifestación de aquello elaborado en dicho soporte dentro de toda la órbita de distribución de los materiales altiplánicos conocidos hasta ahora. De todo ello deriva la exclusividad de la pieza y, por lo mismo, la usamos para reflexionar sobre la denominada "expansión Tiwanaku”, específicamente hacia los Valles Occidentales del Area Centro Sur Andina. En función de lo anterior revisamos y registramos las colecciones cerámicas y su iconografía, en especial, aquellas piezas de la periferia de la esfera de interacción del Estado altiplánico, centrándonos en el valle de Azapa.

Palabras claves: expansión Tiwanaku - "Señor de los Cetros" - valle de Azapa - alfarería - estilo.

\section{ABSTRACT}

This paper aims to contribute to the understanding of the Tiwanaku problem in Arica (Northern Chile), with the "excuse" of the rediscovery of an exceptional vessel that was excavated by G. Focacci in the funerary site Az-71a (valley of Azapa). Most significantly, this painted piece represents the antique image of the "Lord of the Scepters", topic that has not shown up in Tiwanaku pottery, but more typically, in stone sculptures from the altiplano. It would be, in fact, the only object of this sort so far known for the entire altiplano sphere of distribution. The uniqueness of this piece leads us to reflect on the so-called "Tiwanaku Expansion", and more specifically at that which would have taken place in the Westerns Valleys region of the

1 Este artículo forma parte del Proyecto FONDECYT 1970073: "Una exploración de la iconografía del poder en Tiwanaku y su rol en la integración de las zonas de frontera”, dirigido por J. Berenguer, C. Agüero, C. Torres y M. Uribe.

2 Departamento de Antropología, Facultad de Ciencias Sociales, Universidad de Chile. Ignacio Carrera Pinto 1045, Ñuñoa, Santiago, CHILE. Email: mur@uchile.cl
South-Central Andes area. We reviewed and registered existing ceramic collections and their iconography with this in mind, putting particular attention to those pieces found in the peripheries of the Titicaca State, and with a special focus on those found in the valley of Azapa.

Key words: Tiwanaku expansion - "Lord of the Scepters" - valley of Azapa - pottery - style.

Recibido: junio 2003. Manuscrito revisado aceptado: junio 2004.

\section{Introducción}

La intención de este artículo ha sido contribuir a la comprensión de la problemática Tiwanaku y su presencia en Arica, usando como "excusa" el redescubrimiento de una vasija excepcional, proveniente del sitio funerario Az-71a del Valle de Azapa excavado por G. Focacci. La pieza en cuestión, corresponde a un jarro Tiwanaku que exhibe una decoración muy poco corriente en la iconografía de la alfarería de la connotada entidad cultural altiplánica de Bolivia, la cual se desarrolló a orillas del lago Titicaca por cerca de mil años (Ponce 1972).

Al contrario, la iconografía que muestra la pieza a describir en este trabajo sería más propia del excelso arte escultórico de la piedra que caracteriza y se restringe al núcleo altiplánico (Agüero et al. 2003). Al respecto, lo significativo es que la pintura de la vasija reproduce no sólo la imagen, sino también el antiquísimo tema del "Señor de los Cetros", cuya manifestación es prácticamente inexistente en la alfarería Tiwanaku. Esta sería la única expresión de aquello elaborado en dicho soporte en toda la órbita de distribución de los materiales altiplánicos conocidos hasta ahora. Incluso, podría pensarse que se trata de una expresión Wari donde esta situación parece ser más común en la cerámica (Cook 1994); sin embargo, un rápido análisis iconográfico del mencionado estilo de Ayacucho en Perú nos indica que las figuras no son de la misma filiación cultural. Vale decir, a diferencia de la que analizamos en este 
trabajo, las piezas Wari son más realistas, elaboradas y apegadas a la iconografía lítica de Tiwanaku.

De todo ello deriva la exclusividad de la vasija y, por lo mismo, la usamos para reflexionar sobre la denominada "expansión Tiwanaku", específicamente hacia los Valles Occidentales del Area Centro Sur Andina (Figura 1). En función de lo anterior recopilamos y revisamos colecciones y trabajos realizados últimamente en cuanto a alfarería e iconografía, en especial desde la denominada periferia ${ }^{3}$ de la esfera de interacción constituida por el Estado del Titicaca (Berenguer y Dauelsberg 1989), centrándonos en el valle de Azapa. En este sentido, a lo largo del presente artículo se combinan resultados del análisis de la iconografía de la litoescultura (Agüero et al. 2003), con el estudio técnico, decorativo y estilístico de la alfarería que ha surgido de una revisión de colecciones cerámicas de los puntos más importantes de la órbita Tiwanaku (Uribe y Agüero 2001 y 2004), los que en conjunto han sido potenciados a través del examen de la vasija aludida desde un marco metodológico y conceptual previamente fundamentado (Uribe 2004). Como consecuencia de ello, se discute en torno al problema y se ofrecen nuevas posibilidades interpretativas que estas expresiones de cultura material nos han inspirado con el tiempo.

\section{La alfarería Tiwanaku en el núcleo altiplánico}

En términos generales, esta alfarería se concibe como una cerámica policroma cuyas formas e iconografía configuran el gran horizonte estilístico del Período Medio de los Andes Centro-Sur, producto de la amplitud que alcanza su distribución así como por su efecto sobre los Andes Centrales (Wallace 1957; Cook 1994). Su largo desarrollo a través del tiempo en Tiahuanaco mismo permite establecer en sus inicios relaciones con Pukara (Fase Kalasasaya), es decir, durante el Período Formativo Tardío o Intermedio Temprano (Ponce 1972). Pero, sin duda, su origen como un estilo particular se remonta al tipo Qeya, correspondiente

Utilizamos el concepto de centro-periferia como un esquema ordenador, sin adherir necesariamente al modelo sociopolítico planteado para Tiwanaku (Kolata 1993), a cuya discusión contribuye en gran medida este trabajo. a la época en la cual aparece y se populariza la cerámica con pintura precocción en Tiwanaku y la iconografía da cuenta de motivos coherentes con los de la litoescultura, convirtiéndose en una importante fuente de inspiración para su evolución y diversificación posterior (Rydén 1947 y 1957). Lo anterior ha permitido reconocer una etapa Clásica (Fase IV) y otra Decadente o Expansiva (Fase V) que se traducen respectivamente en una gradual abstracción y geometrización de las imágenes (Bennett 1956 [1934]; Ponce 1972). Precisamente, es en dichos momentos donde se centran varios estudios especializados sobre este arte, puesto que tales clases de piezas son las más abundantes y las que se distribuyen fuera del lago Titicaca (Goldstein 1985; Rivera 1994), alcanzando el actual territorio chileno (Uribe y Agüero 2004).

De hecho, su presencia más allá de la cuenca del lago ha permitido establecer situaciones de distinto impacto en los desarrollos locales en especial de los Andes Centro Sur, por lo cual también ha recibido distintas denominaciones. De este modo, en el importante centro de Moquegua, en el extremo sur peruano, se reconocen tres expresiones con distintas connotaciones histórico culturales pertenecientes a las fases Omo, Chen Chen y Tumilaca (Goldstein 1985 y 1990), asociadas a la instalación de una verdadera colonia tiwanakota bastante relacionada con Ilo y Arica en las costas peruano-chilenas (Owen 1993; Uribe 1995). En Cochabamba, al centro este de Bolivia, se ha distinguido una situación similar representada por las cerámicas de las fases Illataco y Piñami (Céspedes 2001), ligada a manifestaciones algo más locales y orientales conocidas como Omereque, Mizque o "Nazcoide". Al mismo tiempo, incluso alrededor del núcleo altiplánico se han comenzado a detectar otras versiones alfareras de dicho impacto como en Puno, Oruro y Potosí en el sureste de Perú y el centro oeste de Bolivia, respectivamente (Browman 1996 y 1997; Lecoq y Céspedes 1997), además de su lejana presencia en San Pedro de Atacama en Chile y con gran probabilidad en parte del Noroeste Argentino (Llagostera 1996).

En este sentido, apreciamos que la dispersión de la cerámica Tiwanaku implica a su vez el surgimiento de interesantes expresiones locales más o menos apegadas a los patrones originales, que nos sugieren distintos niveles de producción y control 


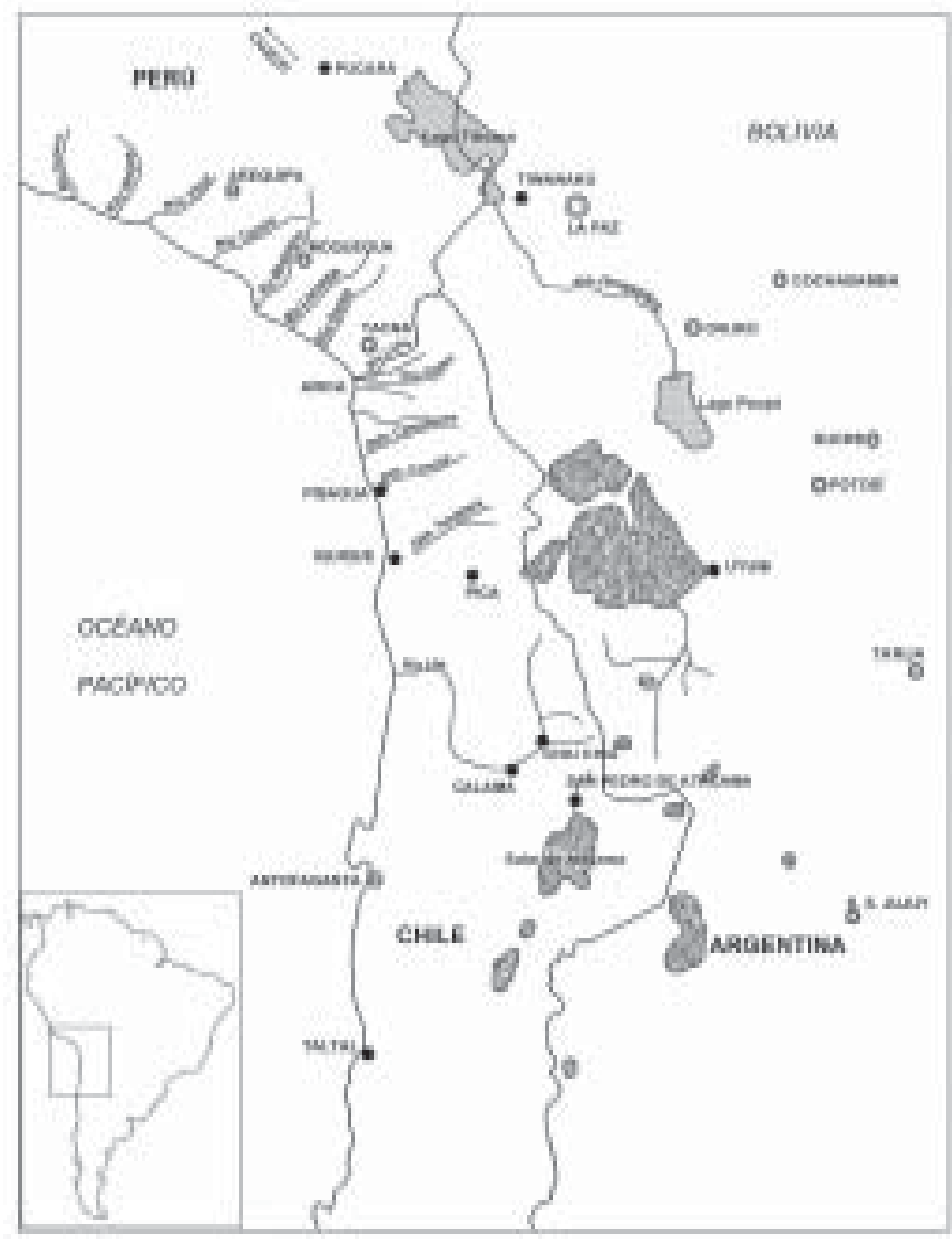

Figura 1. Arica y el valle de Azapa en el marco de la esfera de interacción Tiwanaku en los Andes Centro Sur. Fuente: Berenguer (1998), Uribe y Agüero (2001).

sobre la producción del estilo (siguiendo a Dietler y Herbich 1998). De este modo, tenemos un núcleo que por su largo desarrollo temporal genera un conjunto único de piezas, sólo parte del cual se replica en importantes centros como Moquegua y Cochabamba, a cuyo amparo, además, surgen manifestaciones parecidas o imitativas, por ejemplo, la cerámica Cabuza en Arica (Uribe 1995 y 1999), Omereque en Cochabamba, Puqui cerca de Oruro y Potosí (Lecoq y Céspedes 1997) y quizás Mollo al nororiente del lago Titicaca (Ponce 1957).
Por lo mismo, dicha situación nos sugiere distintos grados de integración o interacción con el Estado altiplánico de Tiwanaku, los que tampoco pueden ser entendidos sin considerar la variable cronológica. En efecto, debe tomarse en cuenta que existe cierto acuerdo respecto a que el proceso de expansión efectiva del horizonte tomó lugar entre los años 800 a 1100 de nuestra era (Goldstein 1990; Owen 1993; Espoueys et al. 1995b; Burkholder 2001; Céspedes 2001), un lapso mucho más tardío y rápido al pensado tradicionalmente, al menos en 
Chile (Berenguer y Dauelsberg 1989), por lo que la variabilidad cerámica parece ser más social que temporal.

\section{Características generales de la cerámica}

Respecto a sus características, hemos podido observar que la alfarería Tiwanaku se distingue, en general, por pastas muy compactas de aspecto sedimentario, aunque en su interior se diferencian por la composición. Algunas parecen naturalmente grasas o muy ricas en caolín y mezcladas con otros materiales igual de finos, mientras que la mayoría es de aspecto arenoso muy homogéneo o magro como si la mezcla hubiera sido tamizada con anterioridad. Sin duda, las primeras parecieran tener un referente en el altiplano donde dichas pastas son bastante típicas por la amplia existencia de depósitos lacustres, y nos parece probable que las piezas han sido trasladas desde allá a varios puntos de la llamada órbita Tiwanaku. Mientras que las segundas se acercan a las más características de zonas bajas u otras, por sus abundantes antiplásticos negros, blancos y cuarzos que le otorgan el aspecto fino, pero granítico a la pasta, por lo cual se podrían estar elaborando en distintos centros de producción fuera del altiplano, aunque con una apariencia semejante. Asimismo, las pastas, sean coladas o arenosas como las denominamos preliminarmente, varían en la proporción de cavidades producidas por burbujas, resistencia y ángulo de la fractura, color y presencia de núcleos producto de la cocción, siendo todos ellos más abundantes o marcados en las primeras y más irregulares en las arenosas.

Con estas pastas las piezas se han levantado exclusivamente por enrollamiento anular a partir de un disco de arcilla que, al mismo tiempo, resulta ser la base de las vasijas. En algunos casos por adhesión se han agregado asas, así como se han realizado adornos plásticos por desplazamiento (p.e., collares, anillos), agregado (p.e., protúberos, modelados) y extracción de material (p.e., incisos, grabados), utilizando las manos casi como únicos instrumentos. Después, para terminar el proceso, las piezas se han llevado a un horno, donde se han cocido en ambiente oxidante bastante regular que deja muy pocas manchas y núcleos, a excepción de las vasijas de pasta colada que por su composición adquieren tonalidades más grises, aunque, al mismo tiempo, alcanzan la mayor dureza.
Las superficies al igual que la pasta tienen tonos anaranjados a café, han sido muy bien alisadas probablemente con instrumentos blandos y revestidas con un delgado pigmento rojo desde el punto de unión de la base con el cuerpo hasta el interior del borde, pues nunca cubren todo por dentro. Por lo mismo, aquí se ha utilizado algún tipo de brocha, así como un pincel para llevar a cabo con gran maestría una decoración de trazos muy finos donde se combinan de cinco a tres colores: blanco, naranja u ocre, negro, rojo o concho de vino y gris o plomo. Posteriormente, también con la misma maestría, se ha utilizado un instrumento blando para pulir en forma homogénea sobre las pinturas hasta alcanzar el bruñido.

La morfología de las vasijas privilegia las formas no restringidas y después las restringidas compuestas o complejas donde se encuentran, en primer lugar, las de perfil independiente y luego las dependientes. Todas ellas comparten las bases planas, a veces anulares en las piezas restringidas; sus labios son convexos, por lo general bien aguzados, sin engrosamiento; mientras que las asas se concentran en las piezas restringidas, siendo en arco, de correa o cinta, ubicadas inmediatamente bajo el labio de los jarros.

La lista la encabezan los vasos altos de geometría casi siempre hiperboloide conocidos como kero, seguidos por los tazones iguales a los anteriores, pero más bajos. Ambos pueden presentar un anillo en la mitad del cuerpo o, la menor de las veces, dos o más cerca del borde y la base. En particular, los vasos suelen exhibir un mamelón o protúbero sobre el labio, ya sea geométrico (subcónico y/o alargado), o bien, figurativo de apariencia zoomorfa que nos sugiere la representación de un ofidio por su cuerpo ondulado. Ocasionalmente, aparecen los vasos con reproducciones de rostros en el cuerpo, los cuales son típicos en el altiplano del Titicaca, así como en los valles de Moquegua y Cochabamba (Ponce 1948; Goldstein 1985; Girault 1990; Céspedes 2001). Se caracterizan por exhibir un trabajo fino en el que destaca una nariz prominente más que aguileña y porque aparecen los adornos cefálicos análogos a los de personajes y rostros frontales de la escultura lítica.

En tercer lugar, se encuentran los jarros que son vasijas restringidas con asa a la altura del cuello, de cuerpos elipsoide y ovoide en el caso de 
las de perfil independiente, y casi siempre esférico-troncocónico en las dependientes, con bordes evertidos que varían indistintamente de hiperboloides a troncocónicos. En estos también aparecen los modelados, donde se repiten los protúberos, esta vez en la unión del asa con el cuello, cuyo aspecto del mismo modo varía de geométrico a figurativo zoomorfo, sugiriendo la representación de felinos, ya que en algunos casos presentan patas y el lomo pintado con manchas o ajedrezado. Por otro lado, a veces la garganta exhibe el pequeño abultamiento que llamamos collar, semejante al que aparece en vasos y tazones como anillo.

A diferencia de otras zonas de la esfera de influencia, prácticamente sólo en el altiplano y los centros regionales Tiwanaku de Moquegua y Cochabamba aparece una variedad formal mucho mayor que incluye también incensarios o sahumadores zoomorfos, escupiteras, botellas, mecheros, ollas y cántaros, además de alfarería no decorada, modelada o escultórica y la cerámica negra pulida con o sin grabado (Bennett 1956 [1934]; Girault 1990; Rivera 1994). Con todo, las vasijas mencionadas, su policromía e iconografía serían lo más representativo de la expansión de este horizonte estilístico.

La variedad de atributos técnicos y morfológicos identificados en este y otros estudios no se asocian directamente a una u otra clase de decoración pintada; sin embargo, hemos notado dos variantes estilísticas principales, independientes como complementarias que son compartidas por las distintas piezas, sugiriendo una producción estandarizada y, en gran parte, controlada por una organización mayor como pudo ser el Estado (Alconini 1993; Rivera 1994; Burkholder 2001). Unos ejemplares pueden realizarse en forma policroma (blanco, gris, naranja, negro y rojo), mientras otros son tricolores e incluso bicolores (blanco, naranja o concho de vino con negro y/o rojo). Sin embargo, tampoco puede olvidarse la existencia de la tercera variante estilística compuesta por las piezas negras pulidas modeladas y/o grabadas, distinguiéndose que algunas piezas pintadas también fueron grabadas.

Según lo anterior, con relación a los estilos pintados, estos los hemos separado respectivamente en Tiwanaku A y B (Uribe 1995 y 1999), cuya contraparte peruana pueden ser Chen Chen y Tumi- laca en el caso de Moquegua, tal vez algunas expresiones de las fases Illataco y Piñami en Cochabamba (Goldstein 1985; Céspedes 2001). En particular, nos referimos con esas variantes a los motivos más destacados dentro del diseño que, por un lado, son las figuras naturalistas elaboradas desde una manera relativamente realista hasta una más esquemática, diferenciándose con claridad de los motivos geométricos, asignables respectivamente a las fases cerámicas contemporáneas Mamani y Acarapi del núcleo altiplánico (Burkholder 2001). Entre los primeros destacan las figuras humanas, de aves, felinos y seres mixtos o "irreales" (Fase Mamani), todos los cuales aparecen de cuerpo entero o sólo la cabeza, representados de frente o perfil cualquiera sea el caso. Por otro lado, los motivos puramente geométricos se encuentran formados por la conjunción, entre otras, de líneas paralelas, onduladas, espirales, triángulos, rombos, cruces y ganchos (Fase Acarapi), a veces acompañados por las anteriores figuras naturalistas. $\mathrm{Al}$ mismo tiempo, nuestra variante $\mathrm{A}$ o naturalista tiende a ser policroma, en tanto la B o geométrica es más bien tricolor o bicolor.

Por otra parte, hasta el momento no podemos establecer una clara recurrencia en cuanto a la configuración de la decoración de las vasijas, aunque lo común es que esta aparezca acotada a su exterior, salvo en los bordes, casi nunca en el interior y en las asas de los jarros. Y, del mismo modo, preliminarmente hemos detectado que el diseño se estructura de manera bipartita. Con todo, ninguna pieza es igual a la otra, sobre todo en los vasos, a pesar de existir una producción a gran escala y estandarizada casi, sin duda, relacionada con especialistas y el Estado.

Respecto al problema temporal, en cuanto se pasa de lo figurativo y policromo a lo geométrico y tricolor o bicromo, no otorgamos connotaciones cronológicas tan radicales a ambas variantes como tradicionalmente se ha considerado dicha situación (Bennett 1936, 1948 y 1956 [1934]; Rydén 1947 y 1957; Wallace 1957; Ponce 1972; Burkholder 2001). Esto, porque incluso en la periferia ambos estilos tienen fechados equivalentes; a veces se encuentran asociados en los mismos contextos e incluso en las mismas piezas, y especialmente porque recién estamos conociendo la incidencia cuantitativa como estratigráfica de uno y otro en las muestras del altiplano mismo (Alconini 1993; Espoueys et al. 1995b; Burkholder 2001). 
Por último, las piezas parecen nuevas, aunque en forma ocasional se detectan algunas "extrañas" prácticas de uso, como son el raspado intencional de bordes y fracturas, "picoteos", agujeros y cruces grabadas sobre el cuerpo o base. Probablemente, como parte de algún ritual, el cual hemos detectado desde Moquegua hasta San Pedro de Atacama, y que creemos debe estar relacionado con el mismo ceremonial mortuorio de Tiwanaku (Manzanilla et al. 1990; Alconini 1993). En este sentido, no se puede dejar de destacar que gran parte de los ejemplares provienen de contextos funerarios, correspondientes a grandes concentraciones de sepulturas a modo de cementerios especialmente en la periferia como Moquegua, Cochabamba, Arica e incluso San Pedro de Atacama. Mientras que en el altiplano prácticamente no se conocen cementerios, aunque sí se hallan como ofrendas funerarias en entierros especiales (Manzanilla et al. 1990). De hecho, en el sitio tipo los enterramientos se encuentran dentro del mismo núcleo urbano y no concentrados en un único lugar, por lo que la mayoría de las piezas también han sido recuperadas de esta peculiar clase de contextos. Por tal razón, resulta evidente que la variabilidad estilística y la consecuente carga simbólica de estas vasijas se encuentra estrechamente ligadas al ritual de la muerte, quizás más que a la vida como lo sugiere la ausencia de restos de la cotidianeidad de sus productores y portadores en gran parte de la órbita tiwanakota. Por lo mismo, pensamos como probable que dentro de esta dimensión de variación estilística, más allá de sus connotaciones temporales, se encuentran los mecanismos ideológicos que integran o articulan al Estado altiplánico (Alconini 1993; Burkholder 2001), en nuestro caso con su mencionada periferia.

\section{Vasijas y figuras de la alfarería Tiwanaku fuera del altiplano}

A diferencia de la litoescultura y su iconografía, la alfarería Tiwanaku es uno de los materiales que, junto a otros artefactos muebles, configuran la esfera de influencia y órbita de interacción con los territorios fuera del altiplano circumtiticaca, correspondientes a Moquegua, Cochabamba y al entorno de cada una de estas regiones. En este sentido, se advierte en ella y su circulación un elemento de carácter más integrador que la exclusividad manifestada por el arte lítico del núcleo. Por tal razón, es que en esta sección nos referi- mos a los aspectos formales e iconográficos compartidos por la cerámica Tiwanaku que "integra" tales territorios, la cual en este sentido hemos rotulado como "expansiva", sin aludir necesariamente a connotaciones cronológicas como también actualmente se plantea para el altiplano (Bennett 1956 [1934]; Rivera 1994).

\section{El estilo "expansivo" de la cerámica Tiwanaku}

De acuerdo a las muestras que hemos podido revisar fuera del altiplano (Uribe y Agüero 2001), hemos distinguido hasta 50 clases de formas de vasijas, correspondientes a las categorías morfofuncionales que llamamos vasos, tazones, trípodes, jarros, "escupiteras", botellas, modelados tridimensionales, sahumadores y ollas (Figuras 2 y 3 ), aparte de aquellos ejemplares exclusivos del núcleo altiplánico y ausentes en la periferia Tiwanaku. Cada una de esas categorías presenta atributos específicos que las caracterizan en términos de simpleza o complejidad del perfil de las piezas, la geometría del cuerpo, luego la del cuello y, por último, los aditamentos o adornos modelados que complementan la morfología de las mismas.

De estos, sin discusión alguna, destacan vasos y jarros por su mayor homogeneidad o diversidad formal, razón por la cual también es posible afirmar que se trata de las vasijas más típicas de la alfarería tiwanakota, parte de una producción estatal más o menos centralizada (Alconini 1993; Rivera 1994). En particular, reconocemos principalmente vasos simples de perfil continuo (Figura 2, a-f, i), en tanto otros son compuestos, porque presentan quiebres en el perfil, producto de las distintas geometrías de los cuerpos de las piezas (Figura 2, g-h, j). Entre los primeros tenemos los vasos kero de cuerpo hiperboloide y troncocónico, en cualquiera de los casos con anillos en la mitad y/o extremos de este, así como protúberos en los bordes que varían de geométricos a naturalistas hasta rostros frontales en el frente análogos a los de la Puerta del Sol (aunque de manera muy ocasional). Los vasos compuestos los separamos por la geometría de sus cuerpos superior e inferior, dentro de los cuales destacamos los vasos "Coca Cola"4 (cuerpo superior esférico e inferior subcilíndrico; Figura 2, h), y los vasos "embudo" (cuerpo superior troncocónico invertido e inferior ci-

\footnotetext{
4 Bautizados con este apelativo por Goldstein (1985).
} 


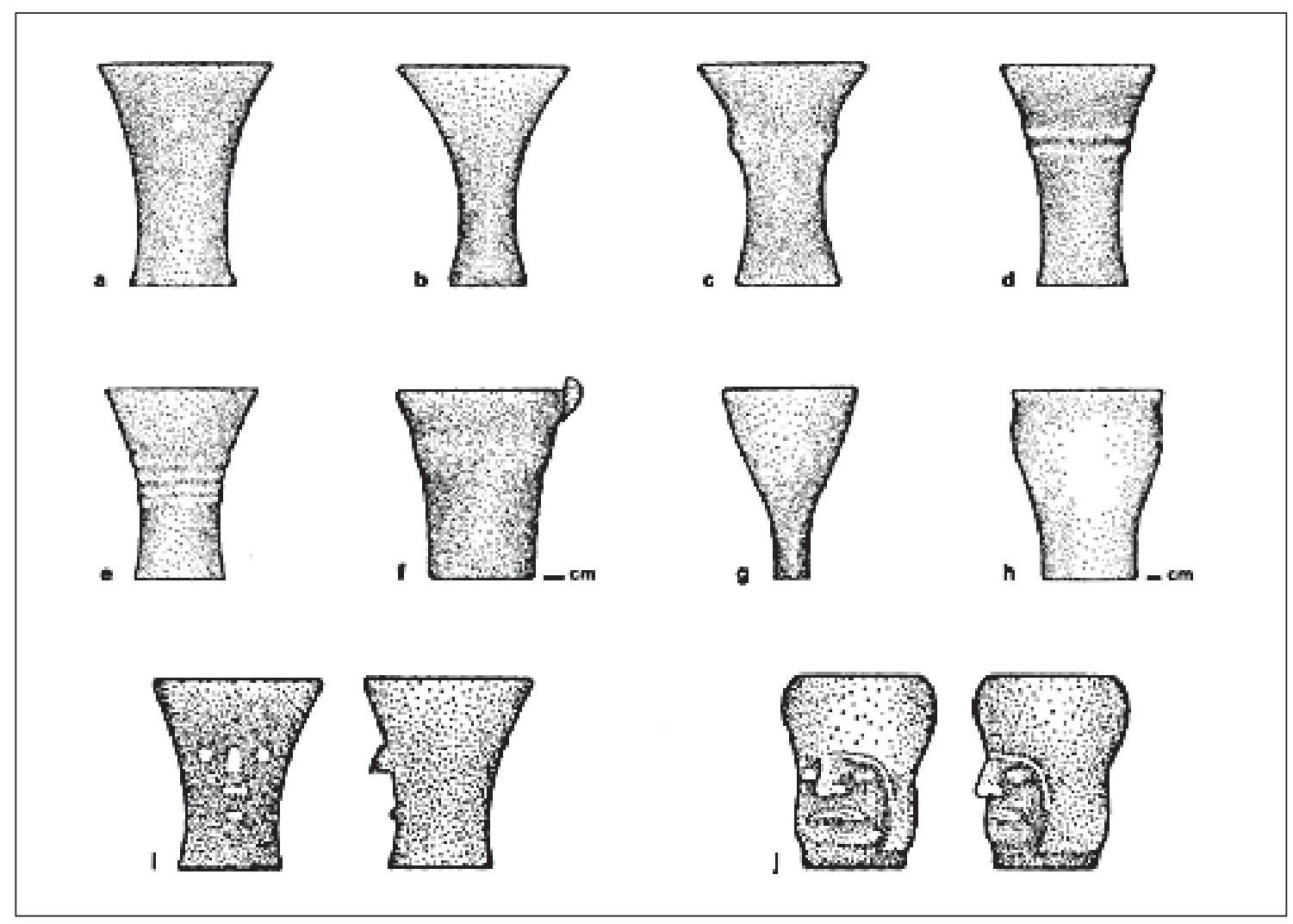

Figura 2. Formas de cerámica Tiwanaku: a-f) vasos-kero; g) vaso embudo de Cochabamba; h) vaso "Coca-Cola" de Moquegua; i-j) vasos retratos. Fuente: Uribe y Agüero (2001).

líndrico muy delgado; Figura 2, g). En todos ellos es posible que se reconozcan los mismos aditamentos anteriores; sin embargo, también se registran otros como los rebordes o labio saliente, las asas, vertederas y, en especial, los rostros frontales que dan nombre a los vasos retratos (Figura 2, $\mathrm{i}-\mathrm{j}$ ), algunos de los cuales incluso pueden llevar representado un "gorro de cuatro puntas". En este caso, los rostros frontales se componen de ojos, nariz aguileña, boca $y$, en especial, en los vasos más elaborados se aprecian orejas, orejeras y hasta bolas de coca en la boca.

Por su parte, los jarros también los hemos separados en simples y compuestos siguiendo el mismo criterio (Figura 3, d y e, respectivamente), es decir, la geometría del cuerpo, la del cuello y las clases de aditamentos que complementan las piezas. A diferencia de lo anterior, en este caso la mayoría corresponde a los más "sencillos" donde diferenciamos aquellos de cuerpo esférico, elipsoides (verticales como horizontales) y ovoides. Sin duda, los ovoides representan la mayor variedad en cuanto el ancho del cuerpo y otros atributos, por lo cual se convierten en los más recurrentes. Todos ellos comparten casi indistintamente cuellos hiperboloides y/o troncocónicos (invertidos), unas veces más estrechos y otras más anchos, cortos o altos; las bases siempre son planas e incluso anulares en algunas ocasiones; las asas son de correa y se encuentran adheridas bajo el borde, así como pueden llevar un protúbero geométrico o naturalista sobre el comienzo. Respecto a los adornos modelados también se registran collares en la garganta, ranuras a la manera de cucurbitáceas a lo largo del cuerpo, asas vertederas y los protúberos naturalistas que pueden corresponder a felinos, debido a que algunos de ellos son representaciones de animales de cuatro patas y cola, tienen el cuerpo moteado (o ajedrezado) e incluso colmillos en el hocico.

Entre los jarros compuestos incluimos vasijas de perfil dependiente o que tienden a ello, puesto que derivarían de las ovoides con un quiebre 


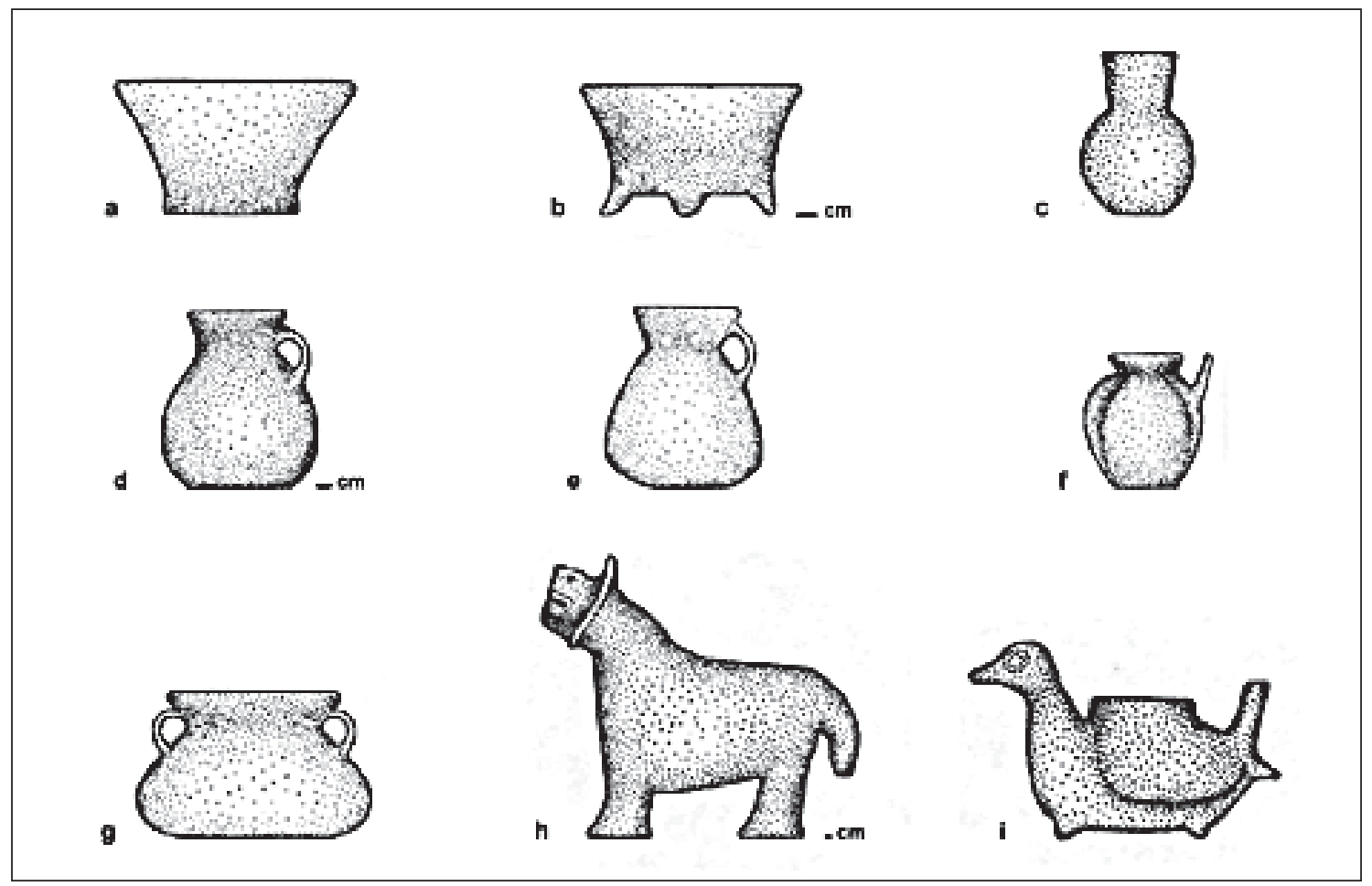

Figura 3. Formas de cerámica Tiwanaku: a-b) tazón y trípode; c-d) botellas; e-f) jarros; g) olla; h-i) modelados zoomorfos. Fuente: Uribe y Agüero (2001).

bastante insinuado a la altura del diámetro máximo, permitiendo diferenciar un cuerpo superior y otro inferior. De este modo, consignamos ejemplares con la parte de arriba semielíptica y troncocónica, mientras la inferior siempre es troncocónica invertida. Aquí se mantienen las mismas características de bases, cuellos y asas, en tanto detectamos muy pocos adornos modelados, los cuales por ahora se reducen a protúberos en el asa y vertederas.

El resto de la gama formal identificada en la periferia Tiwanaku se reparte entre tazones, trípodes, "escupiteras", botellas, sahumadores, ollas y la serie de modelados tridimensionales que asignamos a representaciones ornitomorfas, de camélidos, felinos y fitomorfas (Figura 3, a-c, f-i). De todas ellas sobresalen los tazones que son muy parecidos a los vasos excepto que son más bajos y, prácticamente, no presentan aditamentos.

En definitiva, según nuestros registros (n=323 casos), más del $80 \%$ de las clases de vasijas identificadas es compartido con el altiplano, mientras que apenas un $18 \%$ parece ser exclusivo del nú- cleo Tiwanaku. La muestra con que contamos nos indica el absoluto predominio de los vasos, puesto que corresponden al 38\% del total. En segundo lugar, tenemos a los jarros y tazones con un $17 \%$ y $12 \%$ respectivamente, lo cual significa que no alcanzan a ser la mitad de los anteriores. Por tal razón, es evidente que los vasos son la clase de vasija más típica de la alfarería Tiwanaku y por lo mismo exhiben una diversidad interna tan amplia (Girault 1990; Alconini 1993; Rivera 1994). En cualquier caso, el conjunto constituido por estas tres clases de piezas resulta ser la variedad morfológica cerámica más extendida de dicha entidad, debido a que el resto de las categorías no alcanza una presencia cuantitativamente significativa.

Por su parte, ya que sin duda la decoración pintada es la más recurrente como extendida en el tiempo y el espacio, nos centramos en su descripción. De este modo, hemos diferenciado hasta 51 clases de motivos los cuales fueron definidos a partir de los elementos centrales que configuran un diseño, los que a su vez dicen relación con grandes categorías denominadas figuras naturalistas y 
figuras geométricas (Figuras 4 y 5). De acuerdo a ello, podemos confirmar que esta decoración Tiwanaku se divide entre ambos conceptos, los que, respectivamente, comprenden figuras humanas, de felinos, aves (rapaces o zancudas) y seres mixtos o "irreales", por un lado (Figura 4); por el otro, tenemos una serie de figuras compuestas por aserrados, barras, líneas de distinta clase (rectas, onduladas, zigzag, etc.), rombos, espirales y ganchos (Figura 5). Según nuestra apreciación, además de ser sencillas o elaboradas, las figuras naturalistas se comportan de manera propiamente "realista", si bien aparecen en forma esquemática, abstracta e incluso ambigua cuando tienen un carácter compartido; mientras que en ambos casos (naturalistas y geométricas) pueden ser consi-

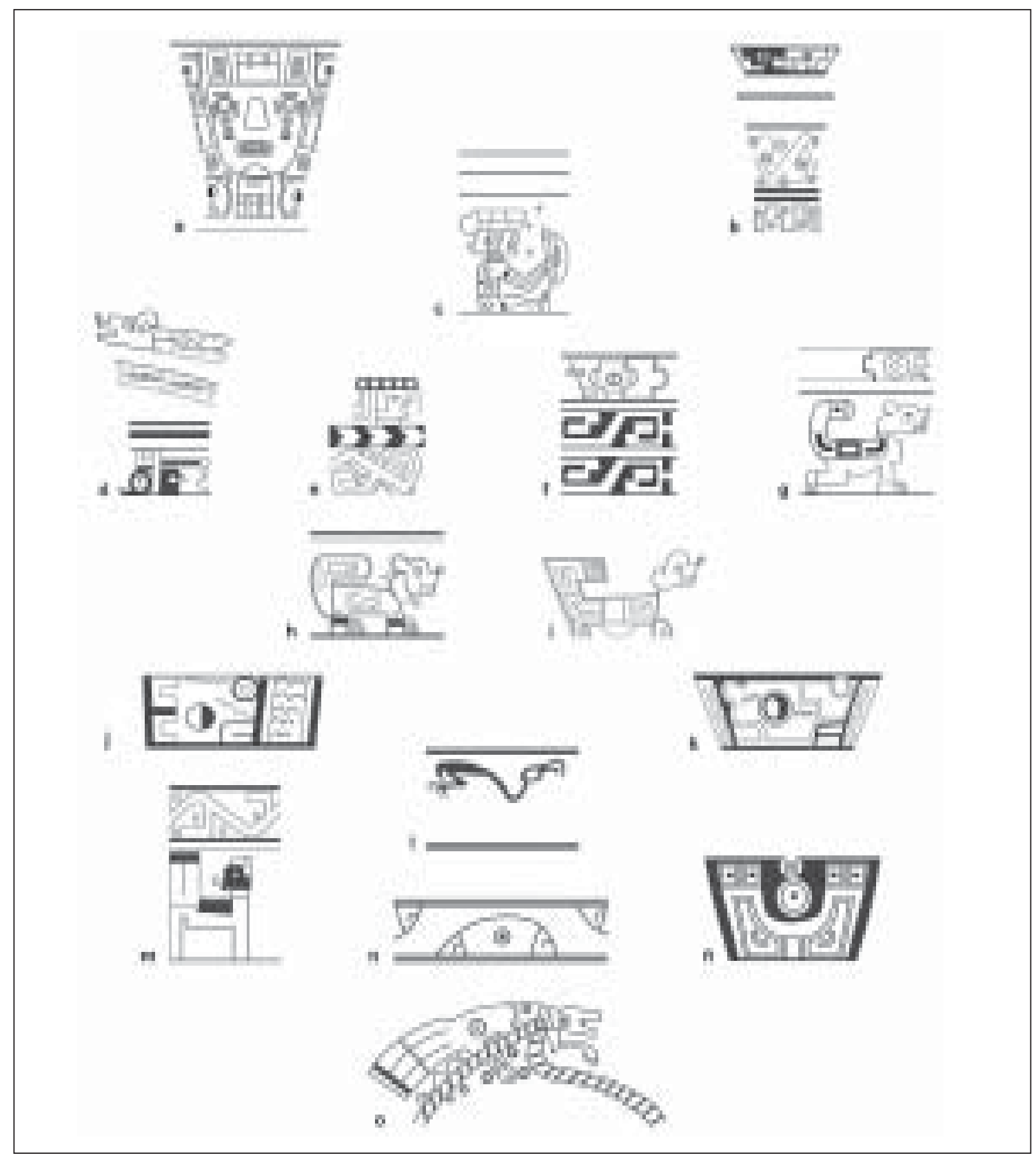

Figura 4. Iconografía Tiwanaku naturalista: a-b) figuras antropomorfas frontales; c-g) figuras antropomorfas de perfil; h-k) figuras zoomorfas-felinos de perfil; 1-ñ) figuras zoomorfas-aves de perfil; o) figura mixta "irreal". Fuente: Uribe y Agüero (2001). 


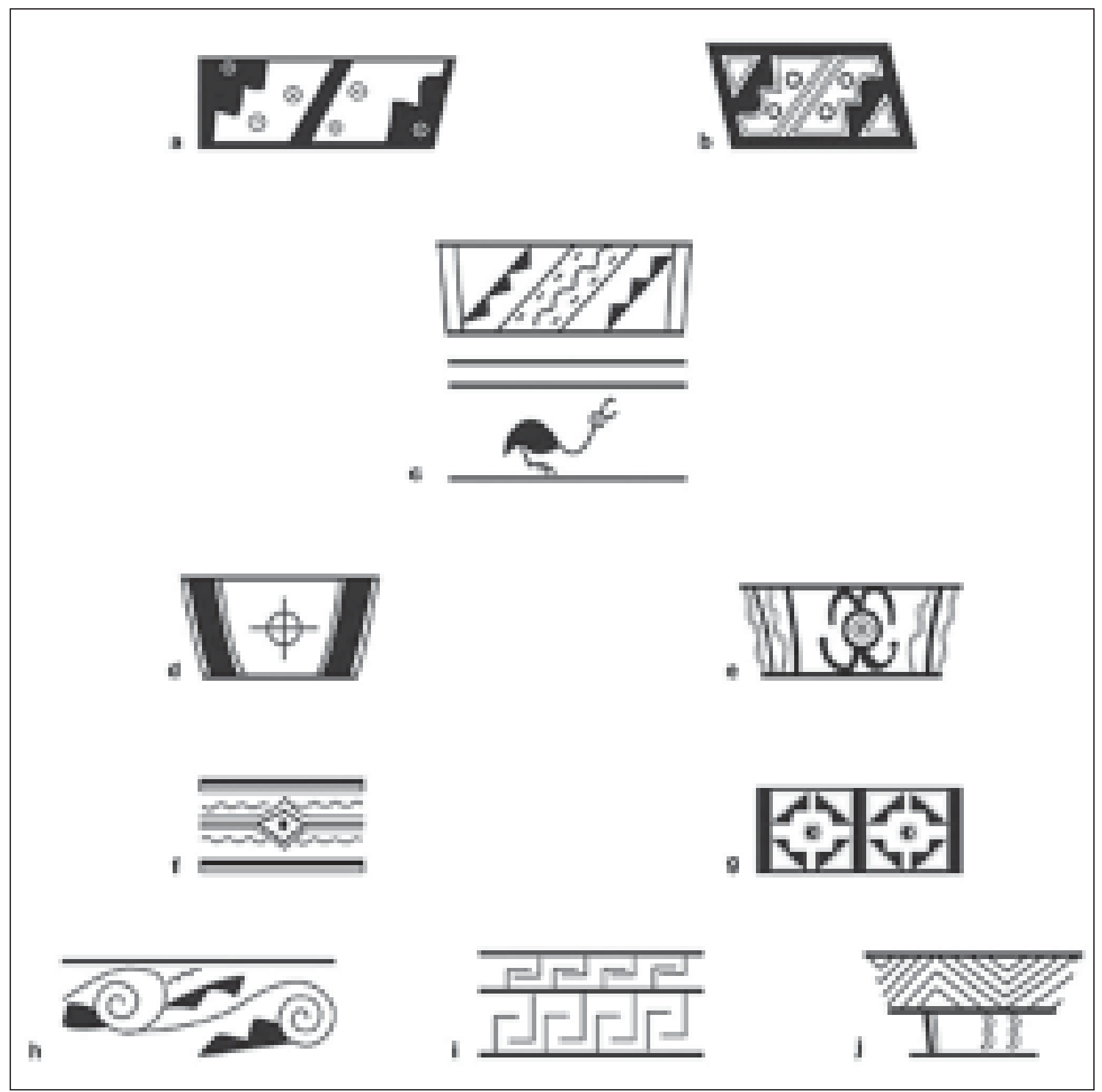

Figura 5. Iconografía Tiwanaku geométrica: a-c) aserrados opuestos; d-e) barras alternadas; f-g) rombos; h) espirales; i) grecas; j) zigzag. Fuente: Uribe y Agüero (2001).

deradas simples y complejas de acuerdo a la cantidad y combinación de elementos o motivos dentro de un mismo diseño. Particularmente, la mayoría corresponde a figuras naturalistas (cerca del $57 \%$ de 51), seguidas por las geométricas (sobre el 37\%), siendo una mínima parte ellos diseños exclusivos del altiplano y ausentes en la periferia tiwanakota (cerca del 2\%).

Lo anterior se traduce en que de la totalidad de motivos registrados la mayoría se hallaría en la esfera de influencia Tiwanaku y sólo una frac- ción menor sería exclusiva del altiplano. De los primeros, casi el $38 \%$ se puede incluir dentro de la categoría naturalistas compuestos por las figuras humanas, de felinos, aves y seres irreales $(\mathrm{n}=323)$. Por su lado, de manera muy similar, los geométricos implican cerca del 30\% registrado, los que incluso pueden igualar a los anteriores si consideramos el $4 \%$ de elementos en esencia geométricos que se usan para destacar los rasgos de vasijas zoomorfas y ornitomorfas, gracias a lo cual dicha clase de motivos alcanza hasta un 33\%. En suma, postulamos que la decoración pintada 
de la alfarería tiwanakota se reparte de manera igualitaria, al mismo tiempo que complementaria, entre figuras naturalistas y geométricas, constituyendo así una temática iconográfica bastante estandarizada. No obstante, al examinar la situación individual de cada una de las clases de motivos vemos que existe una representación mucho más heterogénea, partiendo por el hecho de que más de un cuarto de estos corresponde a diseños sólo registrados en el altiplano (25\%). Más aún, en cuanto a la relación forma-decoración, reconocemos que el $62 \%$ resultan ser casos únicos, en tanto únicamente el $34 \%$ tiene más de una versión, y un $4 \%$ serían versiones propias del altiplano, confirmando que la estandarización señalada no implicó un control total ni tan centralizado de la producción cerámica.

Ahora bien, para efectos de este trabajo nos centraremos en la caracterización de las imágenes naturalistas, en particular las antropomorfas (Figura 4, a-g). Dentro de las figuras humanas se encuentran las representaciones frontales, separables en aquellas de cuerpo entero y las que corresponden sólo al rostro (Figura 4, a-b y d-g). ${ }^{5}$ Respecto a las figuras frontales se cuenta con un solo ejemplar de cuerpo entero (el que describimos más adelante), a diferencia de lo que ocurre con los rostros frontales que son más recurrentes y varían entre esquemáticos y abstractos; en este último caso simples o complejos si le acompañan otras figuras, casi siempre geométricas. En ninguno de ellos la elaboración de la figura llega ser propiamente naturalista, al contrario de lo que ocurre con las de perfil. En general, los rostros frontales abstractos se reducen a trapecios con círculos que representan los ojos, un rectángulo a manera de boca y una línea central que sugiere ser la nariz y, al mismo tiempo, parte la figura en dos (generando rostros de perfil enfrentados). En los esquemáticos el rostro es modelado y la pintura se ocupa para resaltar los atributos de la cara, aunque sobre todo para la realización de un tocado muy semejante al del Personaje Frontal de la Puerta del Sol, entre otras esculturas altiplánicas.

Las figuras humanas de perfil muestran un comportamiento semejante en cuanto aparecen de cuer-

5 También interpretadas como "cabezas trofeos" (p.e., Burkholder 2001). po entero o simplemente como rostro (posibles "cabezas trofeo"), sin embargo, aquí se nota la intención por llevar a cabo una representación mucho más realista (Figura 4, c-g). Pero también se reconocen aquellas imágenes que denominamos esquemáticas, abstractas y ambiguas, en especial, dentro de los rostros de perfil, puesto que otra vez son mínimos los casos de cuerpo entero. Dentro de estos últimos, se aprecian personajes parados o sentados, con un característico tocado cefálico que sugiere ser un turbante, adornos faciales como corporales, asociados a armas en las manos (arcos y flechas), animales o figuras geométricas como acompañantes. Los rostros naturalistas repiten el mismo diseño dentro del cual destaca un ojo mirando hacia arriba, una nariz "enroscada", los dientes como colmillos, pelo largo (trenzas) y tal vez orejeras. Pueden aparecer solos o en coincidencia con los otros motivos antes mencionados. En los esquemáticos el diseño es más geométrico, pues corresponde a un rectángulo o trapecio con boca rectangular, nariz puntiaguda en el frente, un ojo central partido y oreja redondeada en el lugar de la nuca. El ojo aparece inserto dentro de una cruz de ángulos redondeados (a modo de adorno ocular) y la cara partida por la mitad por el uso de distintos colores, lo cual también ocurre en casi todos los casos, e incluso moteada. Asimismo, se le encuentra como motivo único o asociado a otras figuras naturalistas o geométricas. Por su parte, en los rostros que llamamos abstractos sólo se mantienen el ojo central y lo que podría ser la boca, aunque a la altura de la nariz; mientras que en los ambiguos una mitad parece humana y la otra es la cara de un felino, compartiendo un mismo ojo.

Concluyendo, en la periferia Tiwanaku las figuras humanas o antropomorfas resultan ser las imágenes más populares dentro de las naturalistas, sea de cuerpo entero o sólo la cabeza, de frente o perfil $(16 \%)$. Después se encuentran las de felino y ave (Figura 4, h-ñ), como conjunto en proporciones semejantes a las anteriores e inclusive levemente superiores $(9 \%$ y $8 \%)$, pero que por separado pueden ser consideradas solamente la mitad de aquellas. Todo esto nos sugiere una relación conceptual muy parecida a la que exhibe la iconografía de la litoescultura de la Puerta del Sol, en cuanto existe una tríada de imágenes que se organiza de manera jerarquizada (Cook 1994; Agüero et al. 2003). En nuestro caso compuesta por las figuras humanas en lo más alto de la escala, las de felinos 
y aves subordinadas a ellas, pero en proporciones semejantes.

Producción y circulación cerámica en la periferia de Tiwanaku

Dentro de esta jerarquía de formas y decoración establecida por la producción de las piezas Tiwanaku, a nuestro parecer, Cochabamba sería lo más cercano al patrón cerámico altiplánico, sobre todo por su iconografía (Céspedes 2001). Porque, según este estudio, esto se debe al predominio de los vasos y una decoración basada en imágenes naturalistas y geométricas que se realizan en proporciones equivalentes. Sin embargo, aparte de otros atributos, algunos de sus vasos llegan a adquirir un carácter "propio" de los valles orientales, pues varios son marcadamente hiperboloides, aparece el vaso embudo y la policromía incluye el color gris de manera preponderante. Por otro lado, los motivos antropomorfos predominan por sobre los felinos en la decoración, acompañados después por las aves, representadas por las mismas rapaces que aparecen en la litoescultura. En tanto, los motivos geométricos más característicos de Cochabamba serían los escalonados o aserrados y espirales. En suma, aquí se estarían reproduciendo a cabalidad ciertos patrones formales e iconográficos típicos del Estado altiplánico, los cuales incluso estarían llegando a zonas tan lejanas como los oasis de Atacama (Uribe y Agüero 2001). En efecto, en San Pedro predominan los kero y las imágenes de la decoración, relacionadas con aves rapaces y felinos, que se caracterizan por un estilo naturalista bastante cercano al de la litoescultura, lo cual le otorga un carácter indudablemente exclusivo a las piezas que nos sugieren relaciones de alto nivel entre sus portadores y las poblaciones locales, acompañadas por otros materiales cochabambinos (p.e., vasos embudo y ejemplares Omereque). Es decir, de la misma manera que lo hacen la metalurgia, los objetos de madera incluidas las tabletas para el consumo de alucinógenos, los huesos pirograbados y los textiles (Uribe y Agüero 2004), dentro de un patrón más "directo" que en otros casos de la esfera de influencia (Berenguer 1998).

En cambio Moquegua, si bien como segundo centro también se apega a los principios estilísticos altiplánicos originales, exhibe sus propias innovaciones ejemplificadas por la presencia de los vasos troncocónico-cilíndricos, de tipo "Coca-
Cola" y vasos retratos, además de la notoria recurrencia de jarros. Del mismo modo, la tricromía basada en los colores naranja (o concho de vino), negro y rojo llega a ser muy común, mientras que los motivos pintados más populares son los geométricos, destacando los aserrados opuestos y las barras intercaladas. Por su parte, dentro de las imágenes naturalistas las zoomorfas desplazan a las humanas, destacando las aves, pero esta vez con apariencia de zancudas más que de rapaces, distinguiéndose después los felinos y, por último, las figuras antropomorfas. En este sentido, se genera una identidad Tiwanaku de Valles Occidentales que, de acuerdo a nuestras observaciones, se ve más o menos replicada en Ilo y Arica (Goldstein 1985; Owen 1993; Uribe 1995). Estos últimos casos, de hecho, serían la máxima expresión de lo anterior por cuanto los jarros desplazan a los vasos y la decoración geométrica gana aún más terreno, ya que incluso se reproduce a nivel local por medio de la cerámica local llamada Cabuza, rica en líneas onduladas, triángulos y casi nula en alguna clase de naturalismo. Por lo mismo, creemos que el principal nexo de Tiwanaku con esos desarrollos de valles bajos y cercanos a las costa se encuentra en Moquegua y alejadamente del núcleo altiplánico, al cual serían bastante marginales de acuerdo a un patrón más indirecto (Berenguer 1998).

Así, desde la alfarería concebimos dos grandes centros productores de cerámica Tiwanaku en la periferia del núcleo altiplánico, correspondientes a Cochabamba y Moquegua, muy integrados tecnológica y estilísticamente al núcleo estableciendo una especie de soberanía productiva en las zonas ocupadas, aunque con clara autonomía cada uno de ellos (Goldstein 1990). En torno a estos se encontrarían poblaciones locales que se integran a la órbita Tiwanaku, aunque con un grado de libertad todavía mayor como lo demuestran en los Valles Occidentales las situaciones de Arica e incluso Ilo y Tacna (Vela 1992; Owen 1993; Uribe 1995 y 1999), y probablemente también las poblaciones de los valles orientales cercanos a Cochabamba (p.e., Mizque). La intención imitativa y el potencial innovador que exhiben las artesanías de tales poblaciones, aparte de la escasez de las piezas tiwanakotas en sus territorios, sugieren una incorporación casi voluntaria o por "efecto de rebote" al entrar en dicha órbita, producto de una particular esfera de interacción. Sin duda, es posible que hubiera algún momento o instancia de 
integración más política de estas zonas "marginales" como lo delata la concentración de dataciones de la presencia cerámica Tiwanaku, por ejemplo, en Arica hacia el 800 y 1100 DC (Owen 1993; Espoueys et al. 1995b), del todo coincidente con los fechados para las fases cerámicas equivalentes Mamani y Acarapi del altiplano (Burkholder 2001). Sin embargo, en estos casos la conexión con el núcleo nunca habría sobrepasado la escala individual producto de la lejanía con el altiplano, obstáculo que no fue salvado a través de ejércitos, caminos y enclaves poblacionales como después lo hicieron los incas. Al contrario, la integración de los locales en zonas como Arica se habría dado casi por "osmosis" debido a la cercanía de los centros "coloniales", como Moquegua, cuyo rol de dispersor cultural e ideológico habría facilitado la inclusión política, pudiéndose producir el impacto Tiwanaku en escalas mayores sólo dentro de un proceso de largo plazo (Uribe 1999), y con claro protagonismo local como queremos destacar en este trabajo.

\section{Tiwanaku y la cerámica en el valle de Azapa}

Hoy día sabemos que la presencia Tiwanaku en el valle de Azapa a través de su alfarería se encuentra restringida a no más de una treintena de piezas completas, así como a un número de fragmentos que no destacan más que los ejemplares enteros (Uribe y Agüero 2001 y 2004).

Junto con ello, sabemos que esas escasas piezas Tiwanaku fueron en su totalidad encontradas en el valle (Figura 6), en ningún caso en la costa, que además son de origen foráneo ligado a Moquegua, su variedad morfológica sólo reproduce poco más de un cuarto del repertorio original, apenas un tercio de los motivos representan su decoración pintada, y que no se han encontrado otros ejemplares típicos del altiplano o sus centros periféricos (p.e., piezas negras pulidas). Más específicamente aún, aquí los jarros predominan cerca del $50 \%$, aunque los vasos son poco más del tercio de las piezas, acompañados por tazones y vasijas modeladas (p.e., aves). Por lo tanto, los jarros son los ejemplares Tiwanaku más populares en Arica, conservando el patrón original del horizonte por cuanto en su mayoría son ovoides y tienen cuello troncocónico, en tanto los vasos que aparecen mantienen el predominio de la geometría hiperboloide y sus adornos, incluidos los vasos retratos.
En términos de decoración, los diseños pintados incluyen figuras naturalistas como geométricas; sin embargo, las últimas llegan a ser casi el doble de las primeras. Dentro de ellas predominarían los aserrados con gancho y opuestos, aparte de varios otros donde destacan las barras intercaladas, los ganchos y zigzags. Por su lado, excepto la ausencia de seres irreales o mixtos, aparece todo el repertorio naturalista compuesto por las figuras humanas y zoomorfas, siendo estas menos de la mitad que las anteriores, pero aves y felinos repartidos en iguales proporciones. $\mathrm{Y}$, si bien no se identifican piezas negras pulidas, el grabado que muchas veces caracteriza a éstas, lo encontramos en piezas pintadas. De tal modo, el estilo Tiwanaku identificado en Arica se caracteriza esencialmente por figuras geométricas y en segundo lugar por las naturalistas, sobre todo antropomorfas, manteniendo el patrón de diseño original. Al mismo tiempo, el soporte más importante en este caso serían los jarros y no los vasos, sin existir una relación directa entre una clase de vasija y un motivo iconográfico determinado, tal como se ha visto hasta el momento.

Ahora, con relación a su comportamiento en los contextos funerarios donde esta alfarería aparece, identificamos dos situaciones en Arica. En primer lugar, que se asocia a pequeños sitios de sepulturas donde el tipo Tiwanaku podría llegar a ser la cerámica representativa, a no ser por la compañía bastante considerable de la cerámica Azapa Charcollo, definida como alfarería de este período y ligado a su esfera de influencia (Uribe 1995). Tal situación la identificamos en Az-103 y Az-141, sitios que por la calidad de sus materiales han sido tradicionalmente caracterizados como lugares exclusivos para el enterramiento de individuos tiwanakotas (Focacci 1983). En segundo lugar, dicha alfarería también se registra en extensos cementerios donde muertos con ajuares de distinta asignación cultural y hasta cronológica comparten el espacio, sectorizándolo o reocupando algunas tumbas e incluso destruyendo su contenido (Berenguer y Dauelsberg 1989). De hecho, el material Tiwanaku, en general, aparece fragmentado como si hubiese sido intencionalmente roto con posterioridad a su uso como ofrenda. Además, en dichos cementerios predomina la cerámica local Cabuza y aparece un número menor de ejemplares Maytas Chiribaya, componente cerámico de otra tradición contemporánea y propia de Valles Occidentales (Espoueys et al. 1995a). Dentro de 

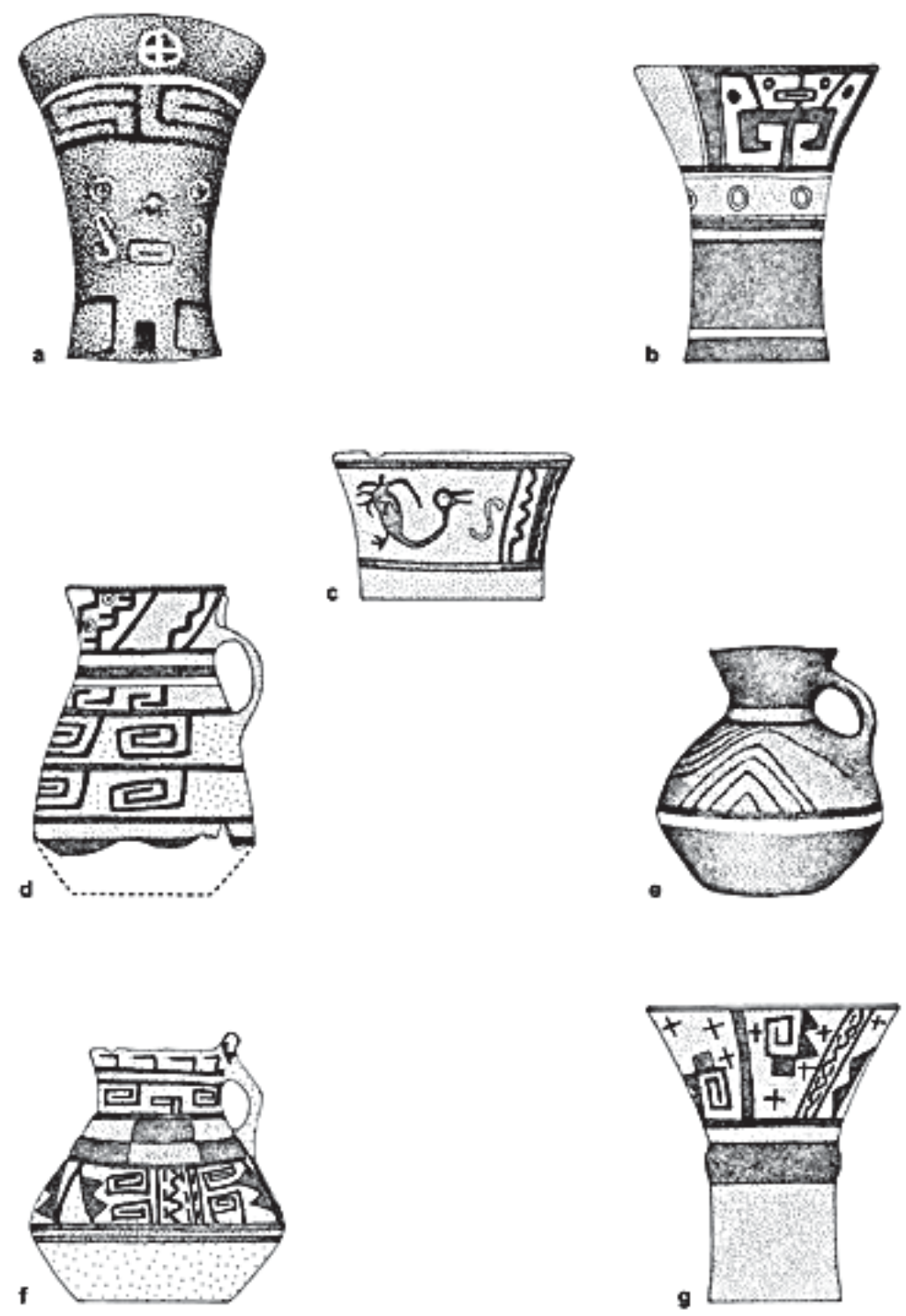

g

Figura 6. Cerámica Tiwanaku del valle de Azapa. Tipo Tiwanaku A (TIW A): a-b) vasos-kero policromos antropomorfos; c) tazón policromo ornitomorfo; d-e) jarros policromos antropomorfo y geométrico; Tipo Tiwanaku B (TIW B): f) jarro tricolor geométrico; g) vaso-kero tricolor geométrico. Fuente: Espoueys y colaboradores (1995b); Uribe y Agüero (2001).

este caso se encuentran sitios como Az-3, Az-6 y Az-71, donde los tipos Tiwanaku y Cabuza prácticamente nunca aparecen asociados en el mismo contexto a pesar de compartir el cementerio, y menos aún con Maytas Chiribaya que más bien pertenece a la tradición no altiplánica (Espoueys et al. 1995a). Por otro lado, Tiwanaku aparece sólo de manera no poco recurrente. En este sentido, creemos que la presencia Tiwanaku, además de ser materialmente esporádica, es excluyente respecto a los portadores de Cabuza u otros grupos (p.e., portadores de Maytas Chiribaya), cuyo único contacto a través de la alfarería lo establece Azapa Charcollo que puede aparecer con cualquiera de ellos, pero siempre en forma separada (Uribe 1999). 
Lo anterior contrasta con el surgimiento de una industria local que "imita" el modelo foráneo y que se convierte en la cerámica más popular del Período Medio de este territorio, llegando a copar los sitios funerarios de la época, un hecho jamás visto en los cementerios previos aun cuando ya existía la alfarería cerca de un milenio antes (Dauelsberg 1969; Uribe 1995, 1997 y 1999). Con ello nos referimos al tipo Cabuza que, a nuestro parecer, reproduce con un estilo propio lo más fácil de percibir de la cerámica tiwanakota, vale decir, sus patrones formales y decorativos básicos. No obstante, esto ocurre a nivel de la mera apariencia de las vasijas, ya que lo que se repite no es la estructura íntegra del proceso productivo y estilístico. Lo anterior queda especialmente evidenciado en la decoración, donde los diseños pintados casi en su totalidad son geométricos y no se aprecia un apego a determinadas reglas de composición; o sea, se replican los elementos decorativos mínimos en las partes que deberían ir, pero sin el referente iconográfico original ni el orden interno que regula su construcción. Por su parte, la decoración modelada también es elocuente en esto, puesto que los motivos casi nunca llegan a adquirir las características naturalistas que son capaces de lograr los artesanos tiwanakotas. Respecto a ello, se nota una habilidad tampoco lograda por los alfareros de Cabuza, cuyas piezas varían desde verdaderas perfecciones hasta ejemplares aberrantes. En definitiva, más parece que la población del valle de Azapa ha optado por incorporar el modelo llegado a los Valles Occidentales, adscribiéndose al estilo foráneo. Todo ello nos sugiere que la presencia Tiwanaku en Arica, por lo menos en cerámica, provoca un profundo impacto estilístico; sin embargo, este se ha desarrollado en forma ocasional, indirecta y/o intermediada. Por lo mismo, Cabuza sólo responde a una intención por repetir los patrones Tiwanaku que nunca es capaz de igualarlos, por ello no es comparable a lo ocurrido en los importantes centros de Moquegua y Cochabamba. Con todo, tampoco es una expresión libre, puesto que Tiwanaku siempre se encuentra presente.

En definitiva, el impacto de Tiwanaku es evidente, pero no nos parece apropiado hablar de una imposición de su cerámica, puesto que su "escasa" presencia se da sólo en sitios funerarios y en cultura material mueble a diferencia de lo que sí habría ocurrido en la cuenca del Osmore en Perú (Goldstein 1990 y 1995-1996), desconociéndose hasta el momento instalaciones que evidencien un proceso de instauración de enclaves de su población a modo de conquistas o "colonias" altiplánicas en Arica como se propuso inicialmente (Berenguer y Dauelsberg 1989). En este sentido, su presencia en el espacio de la muerte nos sugiere que la interpretación del contacto entre ambas entidades y su naturaleza debe, en gran medida, contextualizarse en dicho ámbito. Un ámbito en esencia rico en ceremonialismo (Focacci 1990), razón por la cual también posible de transformarse en un espacio público y, gracias a ello, propicio para manifestar simbólicamente situaciones de la cotidianeidad, con consecuencias sociales y políticas particulares.

Este último punto es el que deseamos profundizar a partir de la excepcional vasija descrita en este trabajo. Nuestra intención ha sido darle un sentido a la presencia de esta pieza dentro del contexto de la expansión Tiwanaku y la integración de distintas entidades culturales que terminaron por conformar la esfera de interacción. En esta ocasión se ha optado por buscar una interpretación desde el simbolismo del jarro considerando que fue parte de las ofrendas de un individuo sepultado en uno de los cementerios de Azapa de aquella época, a pesar de no contar con mayor información acerca del contexto original ni de su cronología absoluta. Salvo por la presencia de cestos, cucharas y cajas de madera de la tumba que, en cualquier caso, no la hacen muy distinta del resto de las sepulturas del momento, específicamente perteneciente a la denominada Fase Cabuza (Focacci 1990).

\section{Un jarro Tiwanaku de Azapa}

Gracias a las excavaciones inéditas de G. Focacci en el sitio funerario Az-71, contamos con una exclusiva pieza que sintetiza varias de las observaciones antes hechas, permitiéndonos reflexionar acerca de la producción cerámica Tiwanaku y la expansión de su esfera de interacción, en particular hacia los Valles Occidentales y Arica. A pesar de ello, no contamos con mayores datos de la excavación, sus contextos ni de sus materiales, si bien se estudiaron y publicaron otros sectores del cementerio, aunque con escasa información sobre esta época (Santoro 1980).

Se trata de una pieza de cerámica, con cuello y asa, completa (Figura 7), de unos $26 \mathrm{~cm}$ de alto, análoga a lo que comúnmente denominamos ja- 


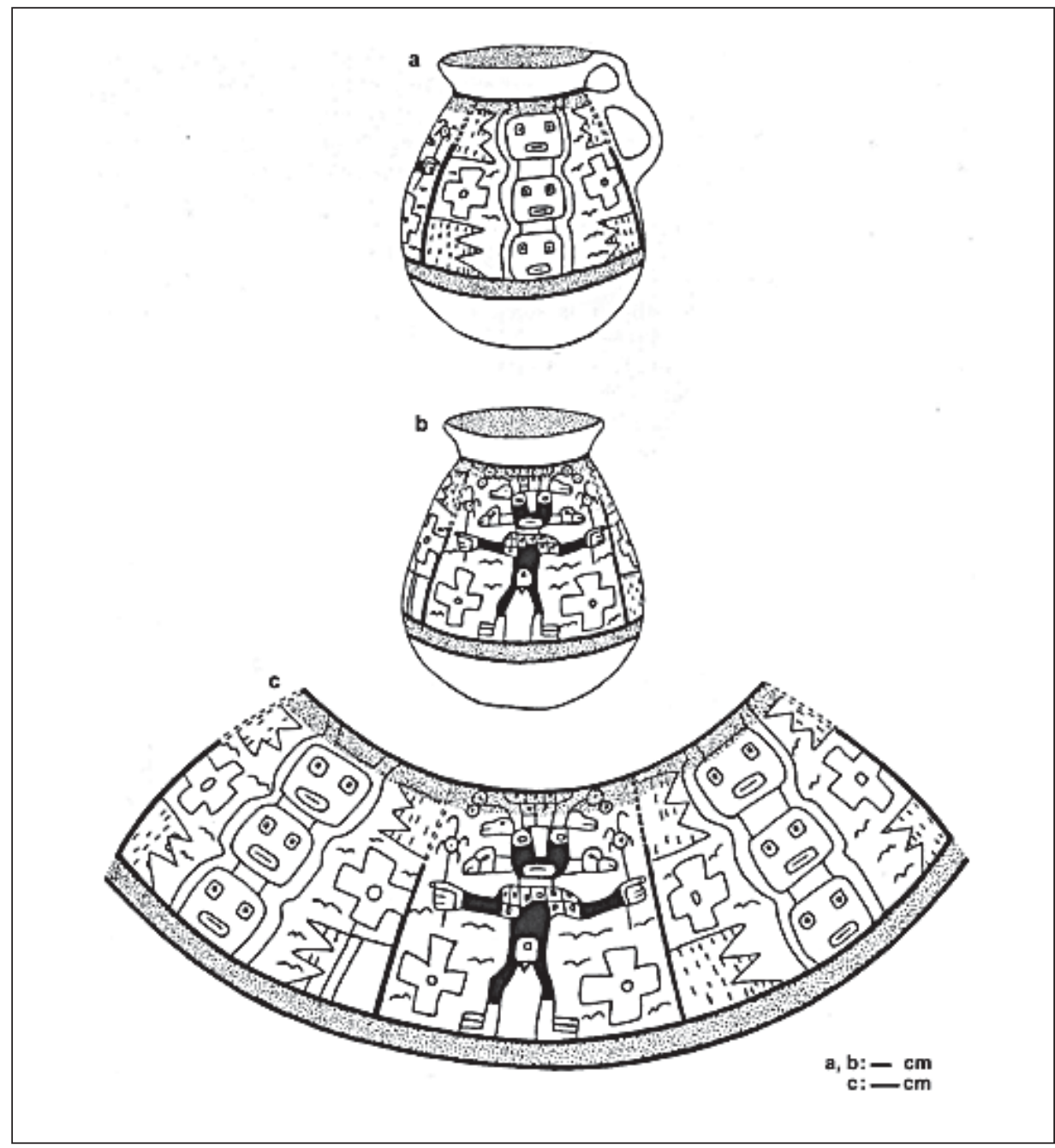

Figura 7. Jarro tipo Tiwanaku B del valle de Azapa (sitio Az-71, Tumba 118, inventariado como 5023), con figura antropomorfa frontal correspondiente al "Señor de los Cetros".

rro, perteneciente a la Tumba 118 del cementerio, se encuentra ingresada con el número 5023 a la colección del Museo Arqueológico de San Miguel de Azapa de la Universidad de Tarapacá y, preliminarmente, la clasificamos como tipo Tiwanaku B o Tricolor (Uribe 1995 y 1999).

En términos más específicos, es una vasija restringida de contorno o perfil inflectado, aunque también podría ser compuesto debido a un ligero ángulo que se genera en el tercio inferior del cuerpo, correspondiente precisamente al diámetro máximo. No obstante, predomina la geometría ovoide del cuerpo con sólo un punto de inflexión a partir del cual se levanta el cuello. Este es de geometría hiperboloide a troncocónica (invertida), más bien ancho y corto. En este sentido, el borde es evertido y presenta un labio convexo, sin engrosamiento. Por su parte, la base es plana por ambas caras. El asa aparece en arco y es de cinta o correa producto de su sección subrectangular, la cual se emplaza verticalmente desde la garganta al hombro de la vasija. Por último, un protúbero de aspecto alargado que se adelgaza hacia los extremos se emplaza sobre el comienzo del asa y se une al labio de la boca. Sin duda, a diferencia del resto de los atributos formales, este es un aditamento a modo de decoración modelada, el cual, además, ha sido pintado generando en conjunto un adorno con posibles referentes figurativos. 
Las superficies fueron cuidadosamente tratadas, por lo que muestran un fino acabado. En primer lugar, se encuentran revestidas con un delgado engobe rojo o café rojizo que abarca todo el exterior desde el punto de unión del cuerpo con la base (excluida esta), hasta el interior del cuello. El mismo sirve de color de fondo en el exterior para un diseño figurativo de aspecto biomorfo pintado en negro, enmarcado entre el cuello y el diámetro máximo del cuerpo por dos gruesas bandas horizontales rojas (concho de vino), a su vez delineadas de negro. Una de estas mismas bandas se distribuye a lo largo y ancho del interior del cuello, mientras que ninguna de las otras partes de la vasija recibe dicho tratamiento, excepto por el protúbero del asa que es atravesado a lo largo por una raya negra ("cola" del protúbero). Incluyendo lo anterior, la pieza fue pulida abarcando todo el espacio cubierto por el revestimiento, con tal delicadeza e intensidad que se logró el bruñido y no se alteró la decoración.

Si bien es difícil aseverarlo por la ausencia de fracturas importantes, da la impresión que la vasija fue hecha con una pasta colada, es decir, muy compacta y homogénea en la que difícilmente se pueden diferenciar antiplásticos o inclusiones de la matriz arcillosa. Esta pasta sería rica en caolín o granítica, muy bien cernida o tamizada, puesto que no suena como loza al golpearla, cuestión que por lo general ocurre en las pastas con mayor caolín. Por otra parte, la manufactura misma corresponde a un moldeado o levantamiento a mano, basado en el enrollamiento anular del cuerpo a partir de un disco que en último término es la base. En tanto, el cuello parece haberse adherido en forma íntegra a la garganta, del mismo modo que el asa y su protúbero. Específicamente en cuanto a esta decoración, el modelado involucra agregado o aplicación de material (pastillaje) y pintura, para lo cual se usaron las manos y un pincel como únicas herramientas.

La decoración pintada, por su lado, implica el uso de un color de fondo rojo a café rojizo (engobe), dos pigmentos distintos a éste (negro y concho de vino) y los mismos instrumentos ya señalados, además de una brocha para aplicar el revestimiento. El pulido se llevó a cabo con implementos relativamente blandos, puesto que no dejaron estrías profundas o marcadas, sino una superficie muy regular y suave; con seguridad, gracias a un alisado previo de gran calidad como lo demues- tran las partes no pulidas (base e interior del cuerpo). La conjunción de este tratamiento y la ausencia de distorsiones en la decoración pintada sugieren la existencia de artesanos de gran calidad que manejan muy bien las etapas de producción de las vasijas. Lo último también es evidente en la cocción de las piezas, la que se realiza en un ambiente o atmósfera oxidante, en cuyo proceso casi no se producen manchas de cocción y donde los núcleos parecen escasos. Por esta razón se puede decir que dicho proceso es bastante regular, quizás completo, lo cual contribuye a configurar las características de la pasta en cuanto a aspecto, fractura y dureza. Al respecto, la destreza técnica expresada por los artesanos que produjeron piezas como ésta no se compadece con su exigua calidad de dibujantes, más cercana a la de neófitos que a la de un verdadero artista.

\section{La figura del "Señor de los Cetros"}

Centrándonos en el diseño pintado, la decoración se encuentra compuesta por una figura central en cuanto esta se halla en el frente de la vasija, es decir, en el lado opuesto del asa, y por otras dos figuras laterales que se ubican a los lados opuestos de la primera (Figura 7c). En tercer lugar, queda un espacio bajo el asa (parte posterior de la pieza) y entre las figuras laterales donde el diseño no pudo ser reproducido producto de la erosión que exhibe esta zona de la vasija. Sólo destaca la gruesa raya que atraviesa el asa y que pertenece al adorno modelado, lo cual desde esta vista posterior puede ser interpretado como la cola de una posible figura zoomorfa.

La imagen central es antropomorfa, puesto que su cuerpo exhibe rostro humano, un tronco que se yergue en dos piernas con pies, los brazos abiertos y manos con dedo pulgar (Figura 7b). A esto se une el hecho que la cara como el resto del cuerpo se dibujaron de frente $y$, en ambos casos, siguiendo una rígida simetría bilateral (derecha como izquierda). Y, si bien la figura en general no es estrictamente abstracta, se identifican ciertas simplificaciones observándose la ausencia de orejas y sólo cuatro dedos en manos y pies, por lo cual hemos determinado que se trata de un diseño esquemático.

En lo particular, la parte superior de la figura se distingue por una cabeza con rostro, cuello y apéndices cefálicos. La cara está constituida por ojos 
redondos con un pequeño círculo central a modo de iris, una nariz rectangular en el medio de estos, una boca parecida, pero dispuesta horizontalmente y con una raya en el centro. Así como toda la figura, el trazado de cada uno de estos elementos es lineal y de aspecto "simple", realizado con pintura negra y sólo el resto del rostro (mejillas y mentón) se rellenó con la misma pintura. Los apéndices cefálicos son cinco y también se distribuyen en forma simétrica. Cuatro de ellos surgen de las esquinas de la cara, se proyectan hacia la derecha e izquierda de la misma y exhiben características zoomorfas, correspondientes a rostros de perfil. En ambas esquinas superiores se distinguen pequeñas cabezas que se encuentran directamente unidas a la cara, con hocico pronunciado, un ojo y un apéndice cefálico formado por una línea curva que culmina en dos círculos con punto central. En cambio, en las esquinas inferiores los apéndices pueden ser adjudicados con mayor precisión a rostros de aves de perfil, pues si bien presentan los mismos elementos constitutivos de los anteriores, los hocicos han sido reemplazados por picos de rapaces. Además, un elemento rectangular a modo de cuello los une a la cabeza del personaje frontal. Por su parte, el quinto apéndice se ubica sobre la cabeza y es más complejo por cuanto corresponde a un diseño geométrico subdividido en dos secciones subrectangulares (la inferior vertical y la superior horizontal), constituidas por elementos cuadrangulares (cuatro arriba y dos a tres abajo), generalmente con un punto inscrito en su interior.

La parte intermedia de la figura corresponde al tronco del personaje, el cual se halla unido a la cabeza por un cuello de forma rectangular, delgado, dispuesto horizontalmente y sin relleno. La mayor parte del tronco, así como las extremidades fueron rellenadas de negro; sin embargo, en el sector superior de esta parte intermedia así como en el extremo inferior, se dejaron espacios libres de pintura donde se trazaron otros diseños que complementan el tronco. Sobre el pecho, ocupando parte de los hombros e incluso el antebrazo, se distingue una serie de pequeños cuadrados con punto inscrito, los cuales se distribuyen en una hilera horizontal que se duplica al alcanzar el comienzo de las extremidades. Por su parte, a la altura de la pelvis se aprecia otro cuadrángulo con círculo central de cuyo lado inferior surge un pequeño triángulo invertido que en primera instancia y por la ubicación del motivo, puede ser interpretado como la expresión del sexo del persona- je. En cualquier caso, aparte del emplazamiento no existe ninguna evidencia de realismo para afirmar esto, pudiendo también corresponder a una especie de taparrabo que ocuparía el lugar de la faja y/o la orilla inferior del personaje descrito para la litoescultura (Agüero et al. 2003).

En cuanto a las extremidades, estas pueden ser consideradas como las partes laterales e inferiores de la figura. En las extremidades laterales se incluyen los brazos, pero también las manos y ciertos objetos que porta cada una de ellas. Como ya fue mencionado, los brazos aparecen abiertos, semilevantados y rellenos con pintura negra, en tanto las manos sólo han sido delineadas al igual que los objetos portados. Por su lado, las extremidades inferiores se caracterizan por estar semiflectadas como señalando el quiebre producido por las rodillas, también están rellenas de negro, pero hasta la altura de los tobillos, haciendo que los pies adquieran el aspecto de "botas". Estos, como las manos, se visualizan de perfil o abiertos hacia ambos lados (derecha e izquierda), exhibiendo tres dedos que se disponen uno sobre el otro. Respecto a las manos, estas aparecen agarrando dichos objetos con cuatro dedos, tres de ellos doblados hacia dentro y con cada uno de los pulgares extendidos sobre los anteriores y mostrando la uña del pulgar.

Los objetos que son sostenidos por las manos, puesto que son atravesadas por estos en el dibujo, se encuentran compuestos por una larga barra en cuyo extremo superior se ubica un círculo con punto inscrito y cuatro apéndices curvos dispuestos más o menos simétricamente en sectores precisos del círculo. En términos bastante sencillos, el motivo adquiere el aspecto de una "flor" y en este sentido no es equivalente a los que aparecen más corrientemente en otras manifestaciones de la iconografía Tiwanaku, donde han sido interpretados como cetros, báculos o armas (estólicas, hachas, etc.). No obstante, con iguales características, estas "flores" aparecen de manera no poco recurrente en personajes y rostros de perfil de otras piezas cerámicas, sobre todo en el altiplano y también en Moquegua (Figura 8a). En este sentido, tales objetos son análogos conceptuales de los "cetros" de la iconografía lítica. Por último, este personaje frontal se halla directamente asociado a dos elementos más, pero externos a él que se ubican a ambos lados de la figura, ocupando casi todo el espacio dejado entre los brazos y las piernas. 

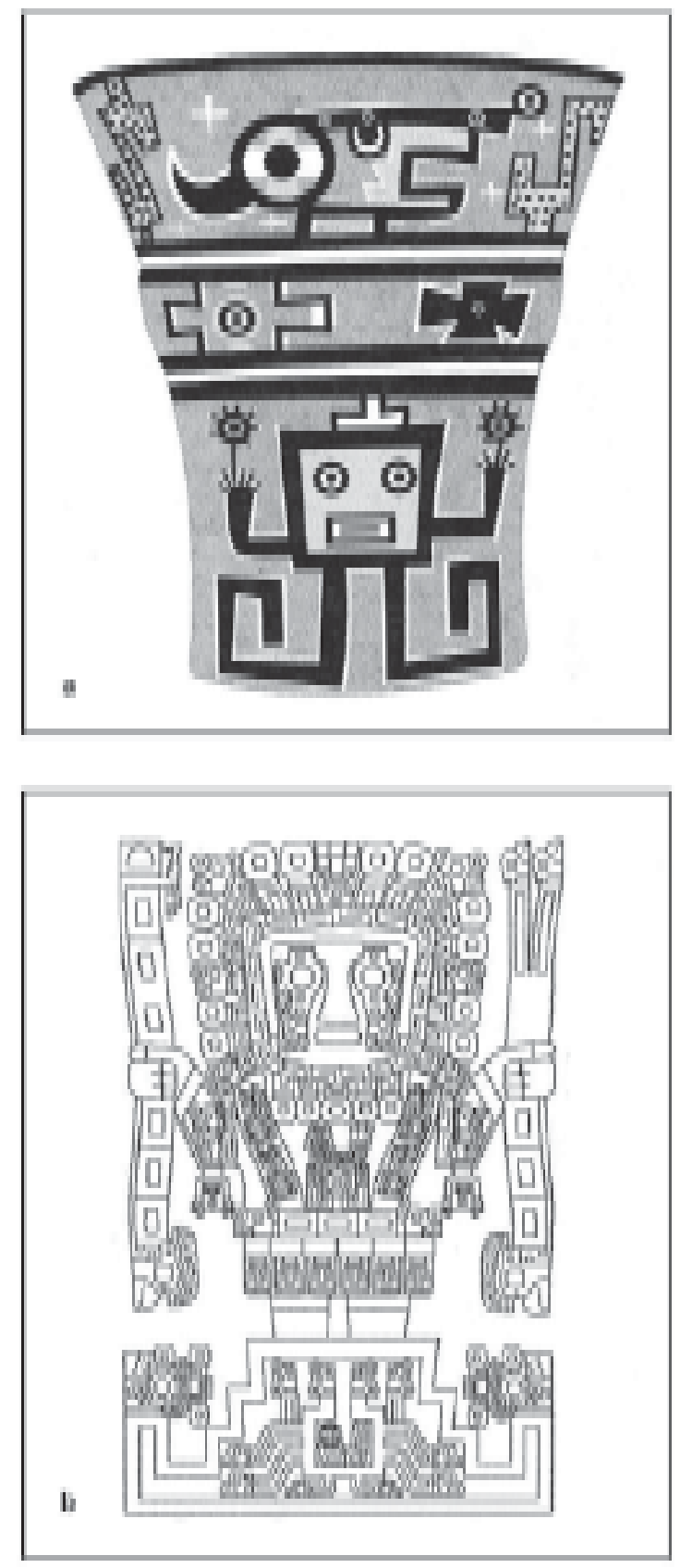

Figura 8. a) Vaso-kero Tiwanaku A del valle de Moquegua (Museo Contisuyo, Perú), con figuras y rostros antropomorfos frontales y laterales, distinguiéndose un personaje frontal equivalente al de la vasija de Azapa; b) Personaje frontal de la Puerta del Sol correspondiente a la clásica representación del "Señor de los Cetros" de Tiwanaku. Fuente: Agüero y colaboradores (2003).

Se trata de dos diseños geométricos negros, con el aspecto de "cruz de Malta" con punto central inscrito, simplemente delineadas y rodeadas por líneas onduladas cortas.
El personaje también se encuentra flanqueado por otros dos diseños más complejos que pueden ser considerados como figuras independientes, recordando a los personajes laterales como los presentes en la Puerta del Sol, ajustándose a los patrones de simetría bilateral de esta iconografía, por cuanto se repiten en forma idéntica en ambos lados (Figura 7a). Cada una de dichas figuras laterales, se compone de una repetición vertical o superposición de tres imágenes biomorfas, correspondientes a tres rostros frontales con ojos y boca como los descritos para la figura central. Estos rostros se encuentran unidos por rectángulos como los del cuello de dicho personaje, pero que en este caso no parecieran cumplir la misma función, puesto que tales elementos de unión terminan por ubicarse sobre la cabeza. Asimismo, los rostros frontales no exhiben apéndices cefálicos, sólo fueron delineados y muestran un reborde externo. Sin embargo, los mencionados motivos se ordenarían en partes superior, intermedia e inferior, de manera semejante al personaje central, junto con observarse elementos laterales. Es así como a la derecha e izquierda de cada figura se ubican dos delgadas barras verticales a las cuales se hallan unidos tres elementos distribuidos uno arriba, otro al medio y el tercero abajo, orientados hacia los rostros frontales. El del medio corresponde a la misma "cruz de Malta" que señalamos para aquel personaje, pero que en este caso aparecen a la altura de la parte intermedia de los tres rostros. Sobre y bajo las cruces se encuentran dos iconos cuandrangulares que terminan en tres puntas dirigidas hacia los rostros, en cuyo interior fueron dibujadas varias sucesiones de pequeñas líneas rectas y onduladas muy cortas, aunque en un caso las rectas atraviesan todo el motivo. En términos sencillos, tales motivos adquieren la apariencia de "banderines", acompañados por líneas onduladas cortas que se ubican entre los espacios libres dejados por el resto del diseño.

En este sentido, el hecho de que estas figuras laterales puedan ser descritas en términos de una partonimia, la cual implica segregar una parte superior, intermedia, inferior y lateral, que se mantengan la simetría, la presencia de un "ser" con rasgos antropomorfos al centro y objetos a ambos lados del mismo, nos sugieren que se trata de una figura análoga a la central, pero desmembrada y sintética. En definitiva, sería parecida en términos de composición o diseño, pero en ningún caso igual en cuanto icono, puesto que los 
rasgos humanos de los rostros laterales en ningún caso alcanzan el realismo y detalle del personaje principal. Más bien, predomina la idea de los acompañantes de perfil como en la iconografía lítica original.

Tales características, en consecuencia, permiten interpretar la iconografía de la vasija en cuestión como una de las imágenes discretas más típicas del repertorio iconográfico de la litoescultura Tiwanaku, analíticamente llamado Personaje Frontal, y tradicionalmente adscrito al "Señor de los Cetros" (Cook 1994; Agüero et al. 2003). Al respecto, queremos recalcar algunas características compartidas con dicha imagen de la litoescultura (Figura 8b).

El mencionado personaje ha sido definido como una figura antropomorfa de visualización frontal, provisto de un tocado con apéndices radiales, con los brazos abiertos y semiflectados hacia arriba, un artefacto largo en cada mano (báculo o cetro) $\mathrm{y}$, a veces, parado sobre un pedestal escalonado. Internamente, este icono se encuentra constituido por motivos que se derivan y agrupan de acuerdo a cuatro partes en que divide a la figura: superior, intermedia, lateral e inferior. En la parte superior se pueden reconocer tres motivos: tocado radial, marco facial y adorno ocular. El primero de ellos se refiere a los apéndices que irradian desde la cabeza del personaje con extremos de diferentes aspectos (cabezas de aves, felinos, peces, etc.); el marco facial es un anillo cuadrangular que rodea su cara y el adorno ocular es un aditamento que circunda ambos ojos. En la parte intermedia, es decir, el tronco de la figura, se han identificado otros motivos que se han denominado pectoral, franjas, faja y orillas lateral e inferior. Las franjas son dos bandas sinuosas que se extienden verticalmente a ambos lados del tórax, mientras que el pectoral es aquello que se ubica al centro del mismo. Por su parte, la faja es una banda recta que ciñe horizontalmente la cintura del icono, en tanto las orillas también son bandas rectas, pero que, como sus nombres lo indican, marcan los límites con las partes laterales e inferior respectivamente. La parte lateral debido a la simetría del diseño se divide en derecha e izquierda; no obstante, ambas están compuestas por extremidades a modo de brazos y lo que estos sostienen en las manos que, tradicionalmente, se han adjudicado a "cetros", la mayoría con elementos biomorfos en sus extremos (p.e., cabezas antropomorfas, de aves y felinos), así como también se distinguen motivos en esencia zoo y fitomorfos. De estos, las manos son menos variables, siempre exhiben sólo cuatro dedos, superpuestos y con uña, donde el pulgar se dispone de manera contraria sobre el resto para dar la idea de agarre del objeto. En la parte inferior, de igual modo, se han segregado hasta dos motivos entre los que se encuentran las extremidades con pies y el pedestal. Los pies, aparte de encontrarse unidos al tronco por un par de piernas, se han construido de manera muy parecida a las manos por cuanto se distinguen los dedos superpuestos y con uñas, aunque siempre en un número de tres y ambos orientados hacia la derecha o izquierda. Con todo, también es posible que estos aparezcan abiertos hacia el exterior y con los dedos reemplazados por otros elementos (p.e., Monolito Bennett), o con los pies de frente sin distinción de dedos. El pedestal, finalmente, es una especie de pirámide escalonada sobre la cual se hallan erguidas sólo unas cuantas versiones del personaje, el que se caracteriza por presentar un elemento geométrico inscrito en el interior y extremidades laterales que terminan en cabezas zoomorfas.

En síntesis, la parte superior del Personaje Frontal se reconoce fundamentalmente por el rostro radiado, la intermedia se identifica por lo que podríamos considerar el atuendo, mientras que la parte lateral por las manos con objetos, y la inferior por estar erguido sobre su piernas, algunas veces arriba de un pedestal. Su construcción permite reconocer, al menos, tres principios composicionales que se consideran convenciones representacionales de la iconografía lítica de Tiwanaku (Agüero et al. 2003), todo lo cual nos parece se reproduce en el personaje del jarro de Arica.

\section{Tiwanaku, su cerámica y una vasija en el valle de Azapa}

El estudio de la cerámica ha sido clave en la reconstrucción del desarrollo Tiwanaku como bien lo establece el detallado trabajo de Alconini (1993). Ella sintetiza cada uno de los estudios previos más importantes de Bennett, Rydén, Ponce y Wallace, centrándose en el problema cronológico de la evolución estilística en directa relación con los cambios sociopolíticos del núcleo altiplánico, los cuales habrían promovido las transformaciones en la producción como circulación del estilo y su relación con la formación estatal y su expan- 
sión. Todos estos estudios indican la existencia de estandarización en la producción cerámica Tiwanaku, pero al mismo tiempo evidencian una manufactura de piezas parecidas, pero no idénticas por lo que se trataría de un estilo compartido, donde sólo cierta producción sería centralmente controlada y cuya gran variabilidad indicaría la participación activa de distintos grupos en este proceso. Así, sólo una parte de la producción sería controlada por el Estado, en cambio, otra gran porción sería producción local dentro como fuera del lago Titicaca, infiriéndose que el estilo compartido responde a una conducta ceremonial compartida, colectiva y pública derivada de una gran religión andina (Alconini 1993). Coherente con lo anterior, ahora se entiende a Tiwanaku como una entidad sociopolítica dinámica imposible de reducir a una mera secuencia temporal, lineal y mecánica.

Dentro de este marco, de la misma manera que lo plantea Burkholder (2001), la variabilidad formal e iconográfica no sólo es cronológica, sino también cultural, social y política. De hecho, las representaciones naturalistas Mamani y las geométricas o abstractas Acarapi, pertenecientes a las tradicionales fases Clásica y Decadente de Bennett, resultan en gran medida ser contemporáneas y no sucesivas en el tiempo, lo cual, según nuestro estudio, se aplicaría a la época expansiva definida por Ponce, si bien la iconografía aparece menos naturalista y más geometrizante o abstracta fuera del altiplano (Goldstein 1985). Por lo tanto, se ha confirmado que la cerámica participó y es informativa de la evolución estatal tiwanakota, directamente ligada a un comportamiento ceremonial manifiesto en notables entierros de ofrendas hechos por distintas entidades sociales y dirigidos por un fuerte grupo de líderes espirituales habitando en los monumentos del Titicaca (Manzanilla et al. 1990). Es decir, junto con la arquitectura y escultura, aunque con su propia identidad iconográfica, la alfarería también formó parte de los soportes religiosos que unieron y complejizaron a las comunidades lacustres. En este sentido, los vasos kero en conjunto con figuras de rostros antropomorfos, felinos, aves y figuras geométricas entrelazadas (que parecieran derivar en aserrados), compondrían el repertorio formal e iconográfico privilegiado de la cerámica de los edificios ceremoniales más excelsos de Tiwanaku como la pirámide de Akapana, donde alcanzarían una gran estandarización seguramente producida por especialistas (Alconini 1993), confirmando su adjudicación a una religión que luego se organiza en una formación estatal.

Paralelo a lo anterior, entonces, una manera de retribuir al ceremonial estatal sería ofrendar con las vasijas de las distintas producciones locales que destacarían por una calidad diferente y su mayor variedad estilística. Nos referimos, por consiguiente, a una religión, para concentrar y acumular a través de ofrendas producidas en contextos de peregrinajes y fiestas con fines de reciprocidad a los especialistas del culto, quienes con esta práctica se enriquecen dominando el acceso y la circulación de los bienes suntuarios hasta que el poder religioso adquiere un carácter más secular, tal cual lo sugiere el abandono residencial de Akapana y su utilización como lugar de ofrendas diversas y menos estandarizadas (Alconini 1993). De acuerdo a ello, es factible que el acceso a cerámica ceremonial por ciertos grupos residenciales sea entendido como un bien de lujo y signo de estatus social, ya que el Estado es quien se encarga de redistribuir los bienes más finos como una manera de afianzar y fortalecer sus lazos con ciertos sectores de la población mediante el sistema de redistribución. El resto de la producción, en cambio, referiría a simplificaciones y copias aplicadas a formas más funcionales y prácticas para las actividades cotidianas y comunes (p.e., jarros), derivadas del estilo compartido con las demás poblaciones locales a través del cual se unen y dependen ambas partes del sistema creado.

Esta situación pareciera no ser ajena a lo que ocurrió fuera del altiplano, donde también confirman su presencia las mismas formas e iconos como elementos recurrentes y significativos que sugieren la adopción de los cánones ceremoniales y cosmogónicos de Tiwanaku, incluso resaltando sus clásicas figuras antropomorfas, y con ello una adscripción de la periferia al orden social altiplánico. Entonces, hemos optado por el análisis de la vasija descrita y su iconografía, pues como ella sugiere parece evidente que la esfera de influencia Tiwanaku se construyó en gran parte de acuerdo a una hegemonía cultural más que territorial (siguiendo a D'Altroy 1987), capaz de imponerse desde sus "colonias" en los Valles Occidentales y orientales y no necesariamente del altiplano (Berenguer 2000; Kolata 1993). Tal hegemonía cultural, en este sentido, dice relación con una ideología Tiwanaku por cuanto logró 
imponer una imagen y estilo de su mundo (Cook 1994); a través, por ejemplo, de la circulación de materialidad que, al mismo tiempo, trascendió en los espacios mortuorios debido a la dimensión pública que el ceremonial involucraba en el ámbito local. Por consiguiente, este habría sido un espacio propicio para desplegar identidades y, más precisamente aún, el grado de interacción entre distintos grupos a través de la circulación de objetos como la cerámica, a partir de lo cual se podría advertir una jerarquización al interior de estas relaciones, según quiénes acceden a los ejemplares más fieles al estilo original, aunque sin implicar un dominio político directo de un pueblo sobre otro. Más bien, esto nos representa el grado de complejidad interna de las entidades locales tanto dentro del altiplano como fuera de este, sin reducirse a la idea de Estado como simple superposición vertical, centralizada y elitista de unidades sociales. Cómo ocurrió e incluso por medio de qué estrategias es algo difícil de precisar todavía, pero parece indudable que dicha complejidad implicó una gran competitividad previa en cada segmento social, de lo cual nos informa la existencia de una vasija como la descrita en el contexto histórico cultural de Arica, por lo menos en cuanto a la relación entre una determinada comunidad y el Estado Tiwanaku.

Según lo anterior, la pieza analizada exhibe una de las imágenes emblemáticas de la temática iconográfica de Tiwanaku (Cook 1994; Makowski 2001). Se trata del personaje frontal más conocido de dicha cultura: el "Señor de los Cetros", fácilmente reconocible por su postura erguida y central, su cabeza con apéndices radiados a modo de tocado y por llevar los brazos abiertos con objetos en las manos. Asimismo, su diseño respeta los principios que caracterizan su representación en la escultura lítica, como la frontalidad, la simetría y hasta la jerarquía, puesto que se ubica justamente en el centro de figuras laterales, asimilables a otros personajes (en este caso rostros frontales). De este modo, se reproduce un aspecto exclusivo del arte Tiwanaku, propio del núcleo altiplánico y en un soporte que, si bien no es el privilegiado para ejecutar dicho arte, también dice relación con un jarro, uno de los más emblemáticos de su estilo en cuanto a producción cerámica doméstica se refiere. Al mismo tiempo, se trata de una de las versiones del estilo original, la cual se asociaría al centro poblacional ubicado en Moquegua, donde se registraría el patrón que vemos reproducido en la alfarería Tiwanaku de Arica. En este sentido, optamos por definir a la vasija como producto del estilo "moqueguano" y no altiplánica, lo cual se observa no sólo en la morfología de la vasija, sino esencialmente en la tricromía utilizada, la clase de pasta preparada y la ejecución esquemática o geometrizante de las figuras.

En consecuencia, un tema exclusivo, aunque recreado de la iconografía Tiwanaku, sería plasmado y transportado por un soporte menos exclusivo, más bien doméstico y, en consecuencia, su mensaje estaría mediatizado no sólo como objeto portable, sino también es muy probable que en su significado. De igual modo, creemos que no todo lo Tiwanaku implica una adscripción al Estado ni convierte de por sí a una localidad en un engranaje más de la estructura u organización estatal, ya sean colonias o clientes (Berenguer 1998). En suma, la fuerza del Personaje de Frontal, en tanto exclusivo del núcleo Tiwanaku y del soporte lítico privilegiado por el arte, se hace circular en ciertos objetos cuya producción y demanda respondería a cada dinámica local, generando competencias por la mayor cercanía con el referente original, apreciándose que el "estilo" ha adquirido un papel activo entre las entidades comprometidas (Sackett 1977; Weissner 1983; Plog 1983; Conkey y Harstof 1990). Al respecto, coincidimos con Alconini (1993) en que un estilo no es estático ni homogéneo, más bien es un sistema abierto y dinámico en continuo cambio que constantemente va recibiendo y transmitiendo nuevas identidades y diferencias, por lo que es lógica la existencia de una serie de estilos como parte de la complejidad social. Y si bien un estilo es la manera en que una sociedad se representa visualmente como un medio de asegurar lazos de solidaridad y dependencia,

"también es un medio para reforzar la diferenciación social mediante la creación de ciertos estilos característicos para cada grupo como un símbolo de estatus que seguramente va cambiando en relación a la propia dinámica social y política" (Alconini 1993:388).

El activo carácter del estilo, entonces, resulta evidente debido a la circulación restringida de una representación tan exclusiva, lo cual aumenta su valor, pero también por la conducta depositacional que implica. Debemos recordar que las piezas 
Tiwanaku, además de nunca ser abundantes en la periferia, en la práctica casi nunca aparecen asociadas a alfarería local como en Arica (Uribe y Agüero 2001 y 2004), donde marcan ciertas particularidades, aunque las tumbas no exhiben mayores diferencias entre ellas (Focacci 1990; Santoro 1980), señalando cierta igualdad social. Sin embargo, a partir de esta misma situación sugerimos que sí existen distinciones entre los portadores de uno u otro bien cerámico, las cuales se definen en términos de grados que establecen una variabilidad jerarquizada de relaciones cerámicas entre lo local y lo foráneo. Por lo tanto, el problema ahora es esclarecer cómo se está activando el estilo y también de acuerdo a los intereses de quién o quiénes. En nuestro caso, no sabemos si esta pieza y otras vasijas de Tiwanaku llegaron a Azapa producto de una importación, un regalo, fue adquirida en Moquegua, si pertenecía a un individuo tiwanakota o a un ariqueño. No obstante, junto con establecer la importancia de la alfarería como un bien altamente simbólico de la ideología altiplánica, creemos que la población local fue la que protagonizó los mayores sucesos en tanto habría sido quien mejor aprovechó esta conexión con ese mundo de los Andes Centro-Sur.

En suma, es indudable la presencia Tiwanaku en Arica a través de la versión moqueguana de su estilo, mas esto no implicaría una integración de la población del valle de Azapa a un modo "colonial", tal como ocurre con la cuenca del Osmore en Perú (Moquegua). Vale decir, de la misma manera que lo han percibido otros investigadores (Goldstein 1995; Goldstein y Owen 2001), en esta situación no encontramos expresados intereses estatales, desplegando patrones arquitectónicos y artefactuales apegados a los del núcleo. Al contrario, estos serían de una escala menor, con probabilidad representando particulares intereses locales, tal vez de ciertos sectores de la población tiwanakota de Moquegua o de grupos Cabuza de Arica estableciendo contactos directos con dicho centro periférico. Esto último, a nuestro juicio, es lo más probable en términos de alfarería, ya que casi desconocemos la introducción de piezas Cabuza en Moquegua y su número es bastante reducido al interior de Ilo (Goldstein 1985; Owen 1993), aparte de la escasa representación de la materialidad foránea, el dominio de lo local, la homogeneidad de sus cementerios y nulo efecto en los asentamientos de Arica. Sin embargo, en este contexto, el efecto parece rotundo, pues los portadores de la materialidad Tiwanaku estarían utilizando su simbolismo como una expresión de exclusividad y en este sentido su prestigio al interior de la misma población de Azapa, con el propósito de legitimar su participación en las redes de interacción social, económica, política o de índole que desconocemos. Con todo, también nos parece que la cercanía de Arica con Moquegua habría terminado por integrar a la mayoría de su población a determinados intereses de aquel centro o a grupos de éste, lo cual habría apoyado el surgimiento de reacciones violentas en Azapa en los momentos en que intensifica la presencia Tiwanaku en la zona alrededor de los siglos IX y $\mathrm{X}$ de nuestra era, apoyándonos en el surgimiento de una tradición cerámica distinta y un grupo con identidad nueva conocida como Maytas (Espoueys et al. 1995a).

Todo lo anterior, finalmente, no hace más que confirmar la gran complejidad social existente en Arica durante el Período Medio, antes que la dominación de un Estado y la formación de una colonia, haciéndonos volver la mirada hacia la dinámica local que hasta la actualidad ha sido opacada por el brillo de Tiwanaku.

Agradecimientos Agradezco especialmente a la editora Carolina Agüero por darme el impulso a publicar este ya viejo trabajo, aunque ahora renovado ejercicio de reflexión. Por otro lado, también me gustaría recordar a Oscar Espoueys y a José Berenguer por introducirme en las problemáticas de Arica y Tiwanaku, dándome su gran apoyo y compartiendo su sabiduría. Asimismo, agradezco al Museo Arqueológico San Miguel de Azapa de la Universidad de Tarapacá, sobre todo a la calidez y profesionalismo de su personal, especialmente representado por la ayuda de Gustavo Espinoza. Por último, agradezco los comentarios de los evaluadores y las ilustraciones realizadas por Paulina Chávez. 


\section{REFERENCIAS CITADAS}

AGÜERO, C., M. URIBE y J. BERENGUER, 2003. La iconografía Tiwanaku: El caso de la escultura lítica. Textos Antropológicos 14 (2): 47-82.

ALCONINI, S., 1993. La cerámica de la pirámide de Akapana y su contexto social en el Estado de Tiwanaku. Tesis de Licenciatura en Arqueología, Universidad Mayor de San Andrés, La Paz.

BENNETT, W., 1936. Excavations in Bolivia. Anthropological Papers 35 (Parte 3), American Museum of Natural History, Nueva York.

BENNETT, W., 1948. A revised secuence for the south Titicaca basin. Memoirs of the Society for American Archaeology 13 (4), Menasha.

-1956 [1934]. Excavaciones en Tiahuanaco. Biblioteca Paceña, Alcaldía Municipal, La Paz.

BERENGUER, J., 1998. La iconografía del poder en Tiwanaku y su rol en la integración de zonas de frontera. Boletín del Museo Chileno de Arte Precolombino 7: 19-37.

2000. Tiwanaku. Señores del lago sagrado. Museo Chileno de Arte Precolombino, Santiago.

BERENGUER, J. y P. DAUELSBERG, 1989. El Norte Grande en la órbita de Tiwanaku (400-1200 DC). En Culturas de Chile. Prehistoria, J. Hidalgo, V. Schiappacasse, H. Niemeyer, C. Aldunate e I. Solimano (Eds.), pp. 129-180. Editorial Andrés Bello, Santiago.

BROWMAN, D., 1996. South Andean federation and the origins of Tiwanaku. En Debating complexity, D. Meyer, D. Dawson y D. Hanna (Eds.), sin páginas. Proceedings of the 26 Annual Conference of the Archaeological Association of the University of Calgary, Calgary.

1997. Political institutional factors contributing to the integration of the Tiwanaku State. En Emergence and change in early urban societies, L. Manzanilla (Ed.), pp. 229-243. Plenun Press, Nueva York y Londres.

BURKHOLDER, J., 2001. La cerámica Tiwanaku: ¿Qué indica su variabilidad? Boletín de Arqueología PUCP 5: $217-249$

CESPEDES, R., 2001. Excavaciones arqueológicas en Piñami. Boletín Museo INIAN, Serie Arqueología Boliviana 9: 1-14.

CONKEY, M. y C. HASTORF (Eds.), 1990. The uses of style in archaeology. Cambridge University Press, Cambridge.

COOK, A., 1994. Wari y Tiwanaku: Entre el estilo y la imagen. Pontificia Universidad Católica del Perú, Lima.

D'ALTROY, T., 1987. Introduction. Transitions in power: Centralization of the Wanka political organization under the Inka rule. Etnohistory 34: 78-102.
DAUELSBERG, P., 1969. Arqueología de la zona de Arica: Secuencia cultural y cuadro cronológico. En Actas del V Congreso Nacional de Arqueología Chilena, pp. 15-19. La Serena.

DIETLER, M. y I. HERBICH, 1998. Habitus, techniques, style: An integrated approach to the social understanding of material culture and boundaries. En The archaeology of social boundaries, M. Stark (Ed.), pp. 233-263. Smithsonian Institution Press, Washington D. C.

ESPOUEYS, O., V. SCHIAPPACASSE, J. BERENGUER y M. URIBE, 1995a. En torno al surgimiento de la cultura Arica. Actas del XIII Congreso Nacional de Arqueología Chilena, T. I: 171-184. Antofagasta.

ESPOUEYS, O., M. URIBE, A. ROMAN y A. DEZA, 1995b. Nuevos fechados por termoluminiscencia para la cerámica del período Medio en el valle de Azapa (Primera Parte). Actas del XIII Congreso Nacional de Arqueología Chilena, T. II: 31-53. Antofagasta.

FOCACCI, G., 1983. El Tiwanaku clásico en el valle de Azapa. Documentos de Trabajo del Museo Regional de Arica 3: 94-113.

- 1990. Excavaciones arqueológicas en el cementerio Az-6, valle de Azapa. Chungara 24-25: 69-124.

GIRAULT, L., 1990. La cerámica del Templete Semisubterráneo de Tiwanaku. CERES, IFEA, La Paz.

GOLDSTEIN, P., 1985. Tiwanaku ceramics of the Moquegua Valley, Peru. Master Thesis, University of Chicago, Chicago.

_ 1990. La ocupación Tiwanaku en Moquegua. Gaceta Arqueológica Andina 18-19 (V): 75-104.

-1995-1996. Tiwanaku settlement patterns of the Azapa valley, Chile. New data and the legacy of Percy Dauelsberg. Diálogo Andino 14-15: 57-73.

GOLDSTEIN, P. y B. OWEN, 2001. Tiwanaku en Moquegua: Las colonias altiplánicas. Boletín de Arqueología PUCP 5: 139-168.

KOLATA, A., 1993. The Tiwanaku: Portrait of an Andean civilization. Blackwell Publishers, Cambridge, Oxford.

LECOQ, P. y R. CESPEDES, 1997. Panorama archéologique des zones meridionales de Bolivia (Sud-est de Potosí). Bulletin d'Institute Francaise d'Etudes Andines 26 (1) 21-61.

LLAGOSTERA, A., 1996. San Pedro de Atacama: Nodo de complementariedad reticular. En La integración surandina: Cinco siglos después, X. Albó, M. Arratia, J. Hidalgo, L. Núñez, A. Llagostera, M. Penny y B. Revesz (Eds.), pp. 17-42. Estudios Regionales y Debates Andinos 91, Centro de Estudios Regionales Andinos Bartolomé de las Casas y Universidad Católica del Norte, Cuzco y Antofagasta. 
MAKOWSKI, K., 2001. Los personajes frontales de báculos en la iconografía Tiahuanaco y Huari: ¿Temas o convención? Boletín de Arqueología PUCP 5: 337-373.

MANZANILLA, L., L. BARBA y M. R. BAUDOIN, 1990. Investigaciones en la pirámide de Akapana, Tiwanaku, Bolivia. Gaceta Arqueológica Andina 20 (V): 81-120.

OWEN, B., 1993. A model of multiethnicity: State collapse, competition and social complexity from Tiwanaku to Chiribaya in the Osmore valley, Peru. PH. D. Dissertation, University of California, Los Angeles.

PLOG, S., 1983. Analysis of style in artefacts. Annual Review of Anthropology 12: 125-142.

PONCE, C., 1948. Cerámica tiwanakota, vasos con decoración prosopomorfa. Imprenta López, Buenos Aires.

— 1957. La cerámica Mollo. En Arqueología boliviana (Primera Mesa Redonda), C. Ponce (Ed.), pp. 35-117. Biblioteca Paceña, La Paz.

1972. Tiwanaku: Espacio, tiempo y cultura. Academia Nacional de Ciencias de Bolivia, La Paz.

RIVERA, C., 1994. Evidencias sobre la producción de cerámica en Tiwanaku. Tesis de Licenciatura en Arqueología, Universidad Mayor de San Andrés, La Paz.

RYDEN, S., 1947. Archaeological researchs in the highlands of Bolivia. Elanders Boktryckeri Aktiebolag, Gotemburgo.

-1957. Andean excavations I: The Tiahuanaco era east of Lake Titicaca. Monograph Series Publication 4, The Ethnographical Museum of Sweden, Estocolmo.

SACKETT, J., 1977. The meaning of style in archaeology: A general model. American Antiquity 42 (3): 369-379.
SANTORO, C., 1980. Estudio de un yacimiento funerario arqueológico del extremo norte de Chile, 1300 AC-1300 DC. Tesis de Arqueología, Universidad del Norte, Antofagasta.

URIBE, M., 1995. Cerámicas arqueológicas de Arica: $1^{\text {a }}$ etapa de una revaluación tipológica (períodos Medio y comienzos del Intermedio Tardío). Actas del XII Congreso Nacional de Arqueología Chilena, T. 2: 81-96. Antofagasta.

_ 1997. Cerámicas arqueológicas de Arica: $2^{\text {a }}$ etapa de una reevaluación tipológica (períodos Intermedio Tardío y Tardío). Actas del XIV Congreso Nacional de Arqueología Chilena, T. 2: 13-44. Copiapó.

— 1999. La cerámica de Arica 40 años después de Dauelsberg. Chungara 31 (2): 189-228.

-2004. Alfarería, arqueología y metodología. Aportes y proyecciones de los estudios cerámicos del Norte Grande de Chile. Tesis de Magíster en Arqueología, Universidad de Chile, Santiago.

URIBE, M. y C. AGÜERO, 2001. Alfarería, textiles y la integración del Norte Grande de Chile a Tiwanaku. Boletín de Arqueología PUCP 5: 397-426.

-2004. Iconografía, alfarería y textilería Tiwanaku: Elementos para una revisión del Período Medio en el Norte Grande de Chile. Chungara, volumen especial, pp. 517-530.

VELA, C., 1992. Tiwanaku en el valle del Caplina (Tacna). Pumapunku, Nueva Epoca 3 (1): 30-45.

WALLACE, D., 1957. The Tiahuanaco Horizon styles in the Peruvian and Bolivian highlands. Ph. D. Dissertation, University of California, Los Angeles.

WIESSNER, P., 1983. Style and social information in Kalahari San proyectil points. American Antiquity 48: 253-276. 